\title{
THE POST-TRANSFUSION SURVIVAL OF PRESERVED HUMAN ERYTHROCYTES STORED AS, WHOLE BLOOD OR IN RE- SUSPENSION, AFTER REMOVAL OF PLASMA, BY MEANS OF TWO ISOTOPES OF RADIO- ACTIVE IRON ${ }^{1}$
}

\author{
By JOHN G. GIBSON, 2ND, ROBLEY D. EVANS, JOSEPH C. AUB, THEODORE \\ SACK, AND WENDELL C. PEACOCK \\ (From the Radioactivity Center, Massachusetts Institute of Technology, Cambridge, Massa- \\ ehusetts; the Medical Clinic of the Peter Bent Brigham and Massachusetts General \\ Hospitals; and the Department of Medicine, Harvard Medical School, \\ Boston, Massachusetts)
}

(Received for publication August 31, 1946)

The modern era of blood transfusions was ushered in by the discovery of human red cell groups by Shattock (1) in 1900 and Landsteiner (2) in 1901. Grouping was later systematized by Jansky (3) and Moss (4). In the course of a few years the paraffined tube method of KimptonBrown (5), the multiple syringe technic of Lindeman (6) and the 4-way stopcock apparatus of Unger (7) came into general use in hospitals for direct transfusions. All of these methods required speed in transferring blood from donor to recipient because of the dangers of clotting.

Agote (8) and Lewisohn (9) introduced sodium citrate as an anticoagulant. This avoided the hazards of clotting in the interval between drawing and administering blood and yet permitted the observance of aseptic precautions. The procedure was much simpler than the direct methods which required surgical teams and operating room technic.

The citrate method came into favor very slowly. Early apparatus described by Hoffman (10) and Brines (11) involved suction for collecting and positive air pressure for injecting. Reactions were common. A review of transfusion procedure by Herr as late as 1925 (12) indicated that the direct was still preferred to the citrate method.

The first successful preservation of human whole blood was accomplished in 1916 by Rous and Turner (13) by the addition of dextrose to a sodium citrate anticoagulant. This solution was

\footnotetext{
1 The work described in this paper was done under a contract, recommended by the Committee on Medical Research, between the Office of Scientific Research and Development and the Massachusetts Institute of Technology, in collaboration with the Peter Bent Brigham Hospital and the Massachusetts General Hospital.
}

used to a limited extent in World War I by Robertson (14). Since the ratio of diluent to cells was high, and the amount of citrate large, the supernatant fluid was removed and the cells given in suspension in Locke's solution. This procedure was complicated and laborious and did not come into general use.

A survey of transfusion practice in common use up to 1938 was made by Levine (15). Sodium citrate was the most widely used anticoagulant and blood was discarded after from 5.to 7 days. Little if any use was made of blood preservatives.

There is now little doubt that many reactions attributed to citrate may have been due to pyrogenic contamination of solutions or apparatus. Wechselmann (16) reported febrile reactions following intravenous therapy in 1911, and Seibert in 1923 (17) showed them to be of bacterial origin. Banks (18) demonstrated that pyrogens could be destroyed by autoclaving. Removal of pyrogens by Seitz filtration was reported by Co Tui (19), and by adsorption on charcoal by Lees (20). The control of pyrogens by simple procedures made possible the development of methods for preparing safe intravenous solutions (21) and blood transfusion apparatus (22).

Further knowledge of blood groups (23) tended to reduce reaction rates. The discovery of the significance of the $\mathrm{Rh}$ factor by Landsteiner and Wiener (24) explained many untoward transfusion effects.

The advent of economical mechanical refrigertors opened the way for the establishment of blood banks, the first of which, in the U. S. A., was established in 1937 by Fantus (25); others followed promptly $(26,27)$. 
Interest in better blood preservation was awakened by rumors of World War II and greatly accelerated by the actual advent of hostilities in 1939 .

De Gowin and his associates modified the original Rous-Turner solution and studied rates of hemolysis (28), potassium diffusion (29), fragility changes (30), and the effect of temperature (31). They made a clinical study of reactions (32) but did not study post-transfusion survival.

Since then numerous reports on survival as measured by the Ashby agglutination technic (33) have appeared in the literature. Wiener and Schaefer (34) concluded that citrated blood survived poorly after 7 days of storage. Preservation for as long as 18 days was obtained with dextrosesaline-citrate solution studied by Mollison and Young (35). These solutions were difficult to prepare since the dextrose caramelized during autoclaving. This was overcome by acidifying the solution with citric acid. In spite of the very low $\mathrm{pH}$, cell preservation was improved (36).

While the beneficial effect of added dextrose was recognized, the necessary facts upon which to base a military overseas blood program were, in the main, not widely known in 1940 . The rate at which cells deteriorated during storage even in the best solutions had not been satisfactorily determined. The rate at which these deteriorated cells broke down in the recipient was not known, and the degree of hemoglobinemia to be expected to follow a transfusion of blood of a given age was a matter of conjecture. The ability of the individual to handle large amounts of plasma hemoglobin was an uncertainty, although the association of hemoglobinuria and renal damage was recognized. There was little knowledge of the degree of normal functional activity retained by those cells not rapidly eliminated after transfusion, nor was it known to what extent the blood-building substance of the destroyed cells would be utilized.

The effect on preservation of mechanical agitation incident to transportation on survival of cells was unknown although De Gowin (37) had shown that spontaneous hemolysis was not increased by shipment by automobile or airplane under refrigeration. Refrigeration was considered necessary, but optimal storage temperatures had not been determined.

Changes in the chemical behavior of the cell during storage in varying concentrations of ci- trate, saline, and dextrose, at varying hydrogen ion concentrations and temperatures, had not been systematically studied, nor had the effect of these variables on the cell membrane been observed. Various in vitro tests had been applied but there was general disagreement as to whether observed in vitro behavior bore any relation to the extent to which these changes were reversible when the cell was returned to the blood stream.

In short, the degree to which cells would remain viable in any solution for a given time, under given conditions of transportation and refrigeration, was unknown. And finally, no one could say how bad a transfusion a normal, or more important, a seriously wounded human could withstand. Therefore, the standards of acceptable transfusion of stored blood, or the maximum safe period of storage, could not be defined.

The purpose of the study reported in this and subsequent papers was to investigate the many solutions recommended as preservatives for human erythrocytes, both as whole blood and in resuspension after aspiration of plasma, to ascertain :

(1) The percentage of survival of red cells, both as whole blood and in resuspension, after refrigerated storage for varying periods ;

(2) The rate at which non-viable stored cells are removed from the blood stream and the extent of re-utilization of iron contained in those cells ;

(3) The effect on survival of depot storage at temperatures ranging from $-4^{\circ}$ to $+40^{\circ} \mathrm{C}$.; and of transportation by land, sea, and air, with and without controlled refrigeration.

\section{METHODS}

The method used in these studies for measuring posttransfusion survival of stored cells by means of 2 radioactive isotopes of iron has been described in previous communications $(38,39,40)$. Donor red cells are tagged by the intravenous administration of radioactive iron $\left(\mathrm{Fe}^{\mathrm{s5}}\right)$. Since the radioactive iron atoms are firmly bound in the hemoglobin molecule, the presence of donor cells in the recipient's blood stream may be detected as long as the cell remains intact and in circulation. The techniques developed afford high accuracy of measurement. The re-utilization of radio-iron from destroyed cells in new circulating red cells can also be measured. Both the percentage of survival and the rate at which deteriorated cells leave the blood stream in the immediate post-transfusion period can be accurately measured, and hence the method offers a basis for the comparison of preservative solutions. 
Recipient pre-transfusion red cell volume was directly measured by transfusion of fresh red cells tagged with $\mathrm{Fe}^{50}$ (39), or by the dye method (41). The radioactive blood used was drawn from the donors into ACD-1 from 1 to 48 hours before it was injected, and was refrigerated from the time of the bleeding to shortly before administration. Whole blood containing 25 to $100 \mathrm{ml}$. of cells (by hematocrit) was aspirated from the collecting bottle with a calibrated syringe and infused directly therefrom. A sample for radioactivity measurement was taken just before administration. The procedure was carried out within a few hours of the receipt of the main transfusion of stored cells.

\section{Experimental subjects ${ }^{2}$}

With few exceptions, as noted, all donors and recipients were young male volunteers 18 to 25 years of age. Only donors with negative Wassermann reactions and no history of malaria, jaundice, or other recent infectious disease were used. Donors were of Group $\mathrm{O}$ and $\mathrm{A}$, and recipients were of all groups. All recipients and most donors were $\mathrm{Rh}$ positive. Donors whose bloods were to be preserved were built up with $\mathrm{Fe}^{\mathrm{ss}}$; those whose cells were used for recipient red cell volume determinations, with $\mathrm{Fe}^{\mathrm{so}}$.

The level of radioactivity induced in individual donors was governed to a great extent by the type of experiments for which their blood was to be used. Thus, if small blood aliquots were to be given, the donor levels were higher, proportionately, than if half or full transfusions were given. Iron dosage was estimated from the nomograms shown in a previous communication (39), so as to yield a minimum of 250 c.p.m. per ml. of recipient's blood. Booster doses were required to maintain adequate levels in donors receiving $\mathrm{Fe}^{60}$ (47-day half life).

Many donors were bled repeatedly, but at not less than 8-week intervals. Donors prepared with $\mathrm{Fe}^{\text {ss }}$ (half-life 5 years) maintained the radioactivity red cell level resulting from the initial series of injections for long periods.

\section{Blood collection}

Blood was collected either by gravity or in vacuum bottles. During every bleeding, the collecting bottle was gently and continuously agitated. A small sample "pilot tube" of clotted donor blood was obtained at the time of bleeding for cross-matching, checking of blood group, and serologic testing.

Recipients were of all 4 blood groups, but all were $R h$ positive. Typings were twice checked. In all transfusions of group A blood and in many group O bloods, donor cells were cross-matched with the recipient's serum. When small transfusions were given no preliminary bleeding was done; when the transfusions were large (over $75 \mathrm{ml}$. of cells) the recipients were usually pre-bled an amount of whole blood at least equal to the quantity they were to receive. Each recipient was used for only 1 transfusion.

${ }^{2}$ Students enrolled in Army A.S.T.P. and Navy V-12 programs and civilian students at Harvard Medical School.

\section{Gravity method}

Blood from donors whose cells were tagged with $\mathrm{Fe}^{\mathrm{ss}}$ was collected into $500-\mathrm{ml}$. Fenwal blood bottles containing the anti-coagulant solution. Blood from donors, used for red cell volume measurements, whose cells were tagged with $\mathrm{Fe}^{\mathrm{s}}$, was collected into 300-ml. Fenwal blood bottles containing ACD-1 solution.

\section{Vacuum method}

Commercially prepared, evacuated bottles of $600 \mathrm{ml}$. or 1,000-ml. capacity containing sterile, pyrogen-free anticoagulant, were used. ${ }^{3}$ The collecting bottle was inverted during the bleeding so that the blood was drawn up through the anticoagulant solution, and the rate of flow was regulated by means of a screw clamp on the rubber tube, keeping it slow enough to reduce foaming to a minimum.

\section{Subdivision}

When aliquots of whole blood from one donor were given to several recipients the subdivision was made shortly after bleeding, portions being transferred from the collecting to smaller storage bottles by gentle suction. Subdivision of all resuspensions was done in like manner, after thorough mixing of cells and diluent. In a few instances multiple aliquots were obtained by bleeding a single donor into several collecting bottles (4 and 6 in Table I).

\section{Resuspension of erythrocytes}

In all red cell resuspension experiments the blood was collected by gravity into $500-\mathrm{ml}$. Fenwal bottles. The period between bleeding and centrifugation varied from 1 to 26 hours. Centrifugation was carried out in the collecting bottle in an unrefrigerated International Model $F$. centrifuge for 35 minutes at 1,800 to 2,000 r.p.m., and the plasma was removed by suction immediately after centrifugation. In some instances most of the "buffy coat" was removed with the plasma. The resuspension solution was added to the packed cells from $1 / 2$ to 27 hours after plasma aspiration. During all these time intervals, except during centrifugation, the blood or packed cells were refrigerated. Resuspension solutions were usually chilled before being added to cold packed cells.

All these procedures were carried out in an essentially dust-free room, on a porcelain-topped table, under ultraviolet radiation.

\section{Storage}

Whole blood and cell resuspensions were stored at 4 to $6^{\circ}$ C. The constancy of the refrigerator temperature range was carefully checked by means of a recording thermometer. Except when briefly removed for culturing, they remained undisturbed until transfused.

\section{Bacteriologic control}

Four to 5 days before transfusion, $10 \mathrm{ml}$. of the whole blood or cell resuspension were aseptically aspirated

\footnotetext{
${ }^{3}$ Prepared by Baxter Laboratories, Glenview, Illinois.
} 


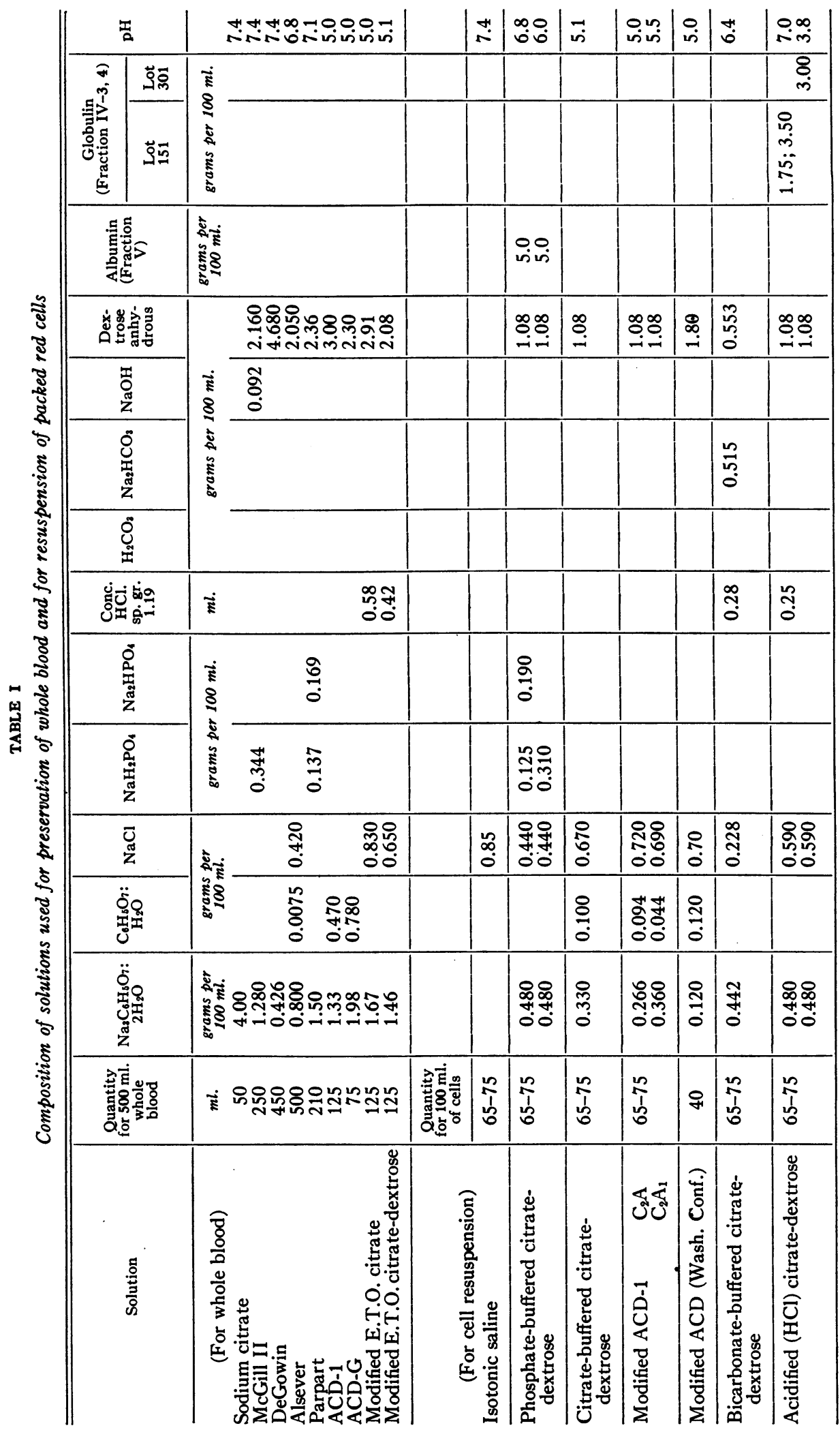


from the storage bottle. Of this, $2 \mathrm{ml}$. were inoculated into each of 2 tubes of thioglycolate broth (for both aerobes and anaerobes), and 3 tubes of tryptose phosphate broth (for aerobes). One tube of thioglycolate and one of tryptose broth were incubated at $37^{\circ} \mathrm{C}$. in air, one of each at room temperature in air, and the third tryptose tube in 10 per cent $\mathrm{CO}_{2}$ at $37^{\circ} \mathrm{C}$. After 2 to 3 days they were subcultured to similar media and to blood agar plates, and maintained at both body and room temperatures. Examination by smearing and gram staining was done at from 2 to 5 days of incubation.

\section{Transfusion of stored blood}

In all experiments, the storage bottle was removed from the refrigerator $1 / 2$ to 3 hours before the transfusion and thoroughly mixed by gentle rotation.

(1) OPEN BURETTE METHOD. All of the blood but 10 or $15 \mathrm{ml}$. was decanted through 4 layers of cotton gauze into a graduated $300-\mathrm{ml}$. salvarsan burette, the delivery tube of which had previously been filled with sterile physiologic saline. The 10 or $15 \mathrm{ml}$. remaining in the storage bottle was used as a representative aliquot for radioactivity measurements and in vitro tests.

(2) TRANSFUsion From storage bottle. After standard Army expendable recipient sets 4 became available, all transfusions were given directly from the storage bottle. These sets, which were designed for use with the standard vacuum bottle, were easily adapted for use with Fenwal bottles by means of a short length of rubber tubing and a glass vent tube. A representative aliquot of filtered blood for radioactivity and in vitro determinations was obtained directly from the delivery tube just prior to the transfusion. The volume administered was determined by water calibration of the collecting bottle.

\section{Radioactivity sampling}

TECHNIC. Fifteen $\mathrm{ml}$. recipient blood samples for radioactivity analysis were taken, with a minimum of stasis, into round bottomed graduated $15-\mathrm{ml}$. hematocrit tubes, using heparin as an anticoagulant. These were spun, stoppered, at 300 r.p.m. for 30 minutes.

SAMPLING SChEDULES. The recipient samples following transfusion were analyzed for radioactivity of both isotopes of iron. On the day of the tansfusion, samples were obtained 20 minutes, 1 to $1 \frac{1}{2}$ hours, and about 4 hours after the transfusion. On the day following the transfusion 2 recipient samples were drawn, several hours apart. In the earlier experiments sampling was carried out to the eighteenth and in some instances to the thirtieth post-transfusion day, a single daily sample being taken for 5 or 6 days after transfusion, followed by triweekly samples. In the later experiments, two samples were obtained on the first and second post-transfusion day, and single daily samples for the next three days, for a total sampling period of six days.

\footnotetext{
4 Supplied by Walter Reed Hospital and American Red Cross Blood Donor Service.
}

\section{Experiments on whole blood anticoagulant-preservatives}

The following solutions, the compositions of which are given in Table I, have been studied. (1) Four per cent sodium citrate; (2) McGill solution, developed and studied by Denstedt (42) ; (3) a modification of the original Rous-Turner solution reported on by De Gowin (43); (4) Alsever's citrate-saline-dextrose solution (27); (5) a phosphate-buffered citrate-dextrose solution recommended by Parpart (44); (6) "ACD-1," and (7) ACD-G, modifications of the Loutit-Mollison acid-citratedextrose solution studied by Rapoport $(45)$; $(8,9) 2$ citrate-dextrose solutions routinely supplied to the European Theatre of Operations (Mediterranean Theatre), and $(10,11) 2$ acidified modifications of the E. T. O. solutions.

In the following description of procedures, "blood" always means blood drawn from a donor previously prepared with radioactive iron $\left(\mathrm{Fe}^{\mathrm{ss}}\right)$. Each blood, or blood aliquot, was transfused into an individual who had never before received radioactive iron in any form. All bloods, or aliquots, were stored at 4 to $6^{\circ} \mathrm{C}$.

\section{(1) SODIUM CITRATE. OPEN BURETTE METHOD}

Experiment Nos. $A, B, C, D$. Five hundred $\mathrm{ml}$. of blood were taken into $50 \mathrm{ml}$. of 4 per cent sodium citrate at room temperature from each of 2 donors. One subject received $1 / 2$ of the blood from the first donor the day it was drawn, and the remainder after storage for 7 days. The blood from the second donor was stored for 7 days, when it was divided into 2 equal portions and transfused. All bloods were prefiltered just prior to administration. The recipients were bled amounts equal to the quantity of citrated blood given just prior to transfusion.

Experiments Nos. 22 through 24. Three hundred $\mathrm{ml}$. of blood were drawn into $30 \mathrm{ml}$. of 4 per cent sodium citrate from a donor who had received both isotopes of iron. The donor had received his first injection of $\mathrm{Fe}^{\mathrm{ss}} 121$ days, and of $\mathrm{Fe}^{50} 24$ days prior to bleeding; thus all $\mathrm{Fe}^{50}$ tagged cells were young cells. Three aliquots of about $100 \mathrm{ml}$. each were transfused after storage for 1,5 , and 8 days.

\section{(2) MCGILL SOLUTION. OPEN BURETTE METHOD}

Experiments Nos. 1 through 5. The 3 components of the solution were sterilized separately and mixed aseptically just prior to taking the blood. Five hundred fifty $\mathrm{ml}$. of blood were taken at room temperature into $275 \mathrm{ml}$. of the solution in a Fenwal 1-litre flask, and the total was divided into 5 equal portions. The aliquots were transfused into 5 individuals after storage for $0,10,14$, 21 , and 29 days.

\section{(3) DE GOWIN'S SOLUTION. OPEN BURETTE METHOD}

Experiments Nos. 18 through 21. The sodium citrate and dextrose solutions were autoclaved separately and mixed just prior to the taking of blood. Three hundred $\mathrm{ml}$. of blood were drawn into $450 \mathrm{ml}$. of the solution in a Fenwal 1-litre flask. The entire bleeding was then divided into 4 approximately equal aliquots. The collection and subdivision of blood were carried out at a tempera- 
ture not over $6^{\circ} \mathrm{C}$. The aliquots were transfused after storage for $0,13,23$, and 36 days.

\section{(4) ALSEVER'S SOLUTION. OPEN BURETTE METHOD}

Experiments Nos. 51, 53, 55. Five hundred ml. of blood were drawn into $500 \mathrm{ml}$. of Alsever's solution, $\mathrm{pH} 6.8$, in a $1,000-\mathrm{ml}$. vacuum bottle, and subdivided by gravity into 5 aliquots of about $200 \mathrm{ml}$. each. Three of these were stored in individual bottles and transfused at 4, 12, and 21 days after drawing. The 2 other aliquots (Experiments Nos. 52 and 54) were used for refrigeration studies, to be reported elsewhere.

(5) WHOLE BLOOD IN BUFFERED CITRATE-DEXTROSE, PH 7.1 (PARPART). OPEN BURETTE METHOD

Experiments Nos. 25 through 27. The citrate and dextrose were autoclaved dry and the phosphate buffer in aqueous solution, in separate containers. Three hundred $\mathrm{ml}$. of blood were drawn by gravity into the dry citrate in a standard collecting bottle. The dextrose was dissolved by adding $130 \mathrm{ml}$. of the buffer and the dextrose-buffer was then added to the whole blood. After thorough mixing, the entire bleeding was divided into 3 approximately equal aliquots. The taking and subdividing of the blood was carried out at room temperature. Hemolysis of the supernatant plasma was observed on the day after the blood was taken but apparently did not increase on storage. The aliquots were transfused after storage for 0,14 , and 27 days.

\section{(6) ACID-CITRATE-DEXTROSE (ACD-1). OPEN BURETTE METHOD}

Experiments Nos. 10 through 13. All 3 components of the solution were dissolved together and autoclaved in a Fenwal blood collecting bottle. Three hundred $\mathrm{ml}$. of blood were drawn by gravity into $75 \mathrm{ml}$. of the solution, and the total amount was divided into 4 approximately equal aliquots. The collection and subdivision were carried out at not over $10^{\circ} \mathrm{C}$. The aliquots were transfused after storage for $2,11,20$, and 39 days.

Experiments Nos. 32 through 34 . The donor from whom this blood was drawn received the first injection of $\mathrm{Fe}^{\mathrm{sb}} 133$ days and his first injection of $\mathrm{Fe}^{\mathrm{s}} 16$ days prior to bleeding. Five hundred $\mathrm{ml}$. of blood were collected into $125 \mathrm{ml}$. of ACD-1 at room temperature, and divided into 4 approximately equal aliquots, 3 of which were transfused after 15,29 , and 41 days of storage. The fourth aliquot, stored 61 days, was not transfused and became hemolyzed.

(7) ACID-Citrate-dextrose (ACD-G). StORAGE BOtTle METHOD

Experiments Nos. 159, 161, 163. Five hundred $\mathrm{ml}$. of blood from each of 3 donors were drawn into $75 \mathrm{ml}$. of the chilled solution, and, after mixing, each blood was divided into 2 aliquots. One aliquot from each donor was stored as whole blood, the other as packed cells (see Experiments Nos. 160, 162, 164). The whole blood aliquots were transfused at 6,15 , and 22 days after drawing.
Experiments Nos. $165,167,169$. Five hundred $\mathrm{ml}$. of blood were drawn from each of 3 donors into $75 \mathrm{ml}$. of the chilled solution, thoroughly mixed, stored at $4^{\circ} \mathrm{C}$., and transfused at 12,19 , and 27 days after transfusion. The recipient of the 19-day-old blood was bled $500 \mathrm{ml}$. prior to transfusion; the other recipients were not bled.

(4 AND 6) COMPARISON OF ACD-1 AND ALSEVER'S SOLUTION pH 6.8. STORAGE BOTTLE METHOD

Experiments Nos. 56, 58, $60(A C D-1) ; 57,59,61$ (Alsever's). The ACD-1 solution was prepared in our laboratories; and sterilized in the collecting bottles. The Alsever's solution was received from Walter Reed Hospital, ${ }^{5}$ transferred to the collecting bottles, and then resterilized. Six hundred $\mathrm{ml}$. of blood were drawn by gravity from 1 donor; $100 \mathrm{ml}$. into each of three $200-\mathrm{ml}$. bottles containing $25 \mathrm{ml}$. of ACD-1, and $100 \mathrm{ml}$. into each of 3 bottles containing $100 \mathrm{ml}$. of Alsever's solution. These aliquots of blood in each solution were transfused after storage for 11,15 , and 21 days.

\section{MODIFICATION OF CITRATE AND CITRATE-DEXTROSE SOLUTIONS USED IN E.T.o. STORAGE BOTTLE METHOD}

At the time these experiments were undertaken, 2 citrate solutions were in routine use in E.T.O. (Mediterranean Theatre) for the collecting of $500 \mathrm{ml}$. of blood: (1) $50 \mathrm{ml}$. of 4 per cent sodium citrate, and (2) $70 \mathrm{ml}$. of 2.5 per cent sodium citrate in 0.85 per cent sodium chloride. It was the practice in E.T.O. to add 30 to $40 \mathrm{ml}$. of 5 per cent dextrose in isotonic saline to the bottles, after $500 \mathrm{ml}$. of blood had been drawn into them. The solutions used in our experiments were commercially prepared in vacuum bottles. All recipients were bled $500 \mathrm{ml}$. within 72 hours prior to transfusion.

(8) E.t.o. Citrate-dextrose. Experiments Nos. 101, 103, 113

(9) e.t.o. Citrate-SAline-dextrose. Experiments Nos. $102,104,114$

Five hundred $\mathrm{ml}$. of blood were drawn by vacuum from each of 6 donors; each of 3 bleedings into $50 \mathrm{ml}$. of 4 per cent sodium citrate; and each of 3 bleedings into $70 \mathrm{ml}$. of 2.5 per cent sodium citrate in saline. Thirty $\mathrm{ml}$. of 5 per cent dextrose in 0.85 per cent sodium chloride solution were then added with a syringe to each bottle. The bloods in the citrate-dextrose solution were transfused after 4,9 , and 14 days, and those in the citrate-salinedextrose solution after 4,9 , and 14 days of storage. The 9-day-old blood was placed in a water bath at about $45^{\circ}$ C. for $\mathbf{1 5}$ minutes before being transfused.

(10) E.T.o. Modification A. Experiments Nos. 95, 97, 99 (11) E.T.o. Modification B. Experiments Nos. 96, 98, 100

Two modifications of the above routine technic were tested. A stock solution of acidified dextrose-saline was prepared, having the following composition:

5 Through the courtesy of Captain John Reichel, M.C. A.U.S. 
Grams per $100 \mathrm{ml}$

Dextrose anhydrous .............. 5.0

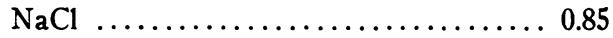

$1 \mathrm{~N} \mathrm{HCl} \ldots \ldots \ldots \ldots \ldots \ldots \ldots \ldots . \ldots . \ldots . . .6 \mathrm{ml}$.

This solution had a $\mathrm{pH}$ of 4.7 , and was autoclaved without caramelization. It was prepared by adding $10 \mathrm{ml}$. of $1 \mathrm{~N}$ hydrochloric acid to 1 litre of the saline dextrose solution in a vacuum bottle.
Modification A. Seventy $\mathrm{ml}$. of the stock solution were added by vacuum to $50 \mathrm{ml}$. of 4 per cent sodium citrate in the original bottle, with sterile precautions.

Modification B. Fifty $\mathrm{ml}$. of the stock solution were added by vacuum to the $70 \mathrm{ml}$. of 2.5 per cent sodium citrate in 0.85 per cent sodium chloride in the original bottle, with sterile precautions.

Three full bleedings were taken by vacuum from individual donors into Modification $\mathrm{A}$, and 3 into Modifica-

\section{POST-TRANSFUSION SURVIVAL OF HUMAN ERYTHROCYTES \\ STORED AS WHOLE BLOOD AT $4^{\circ} \mathrm{C}$.}

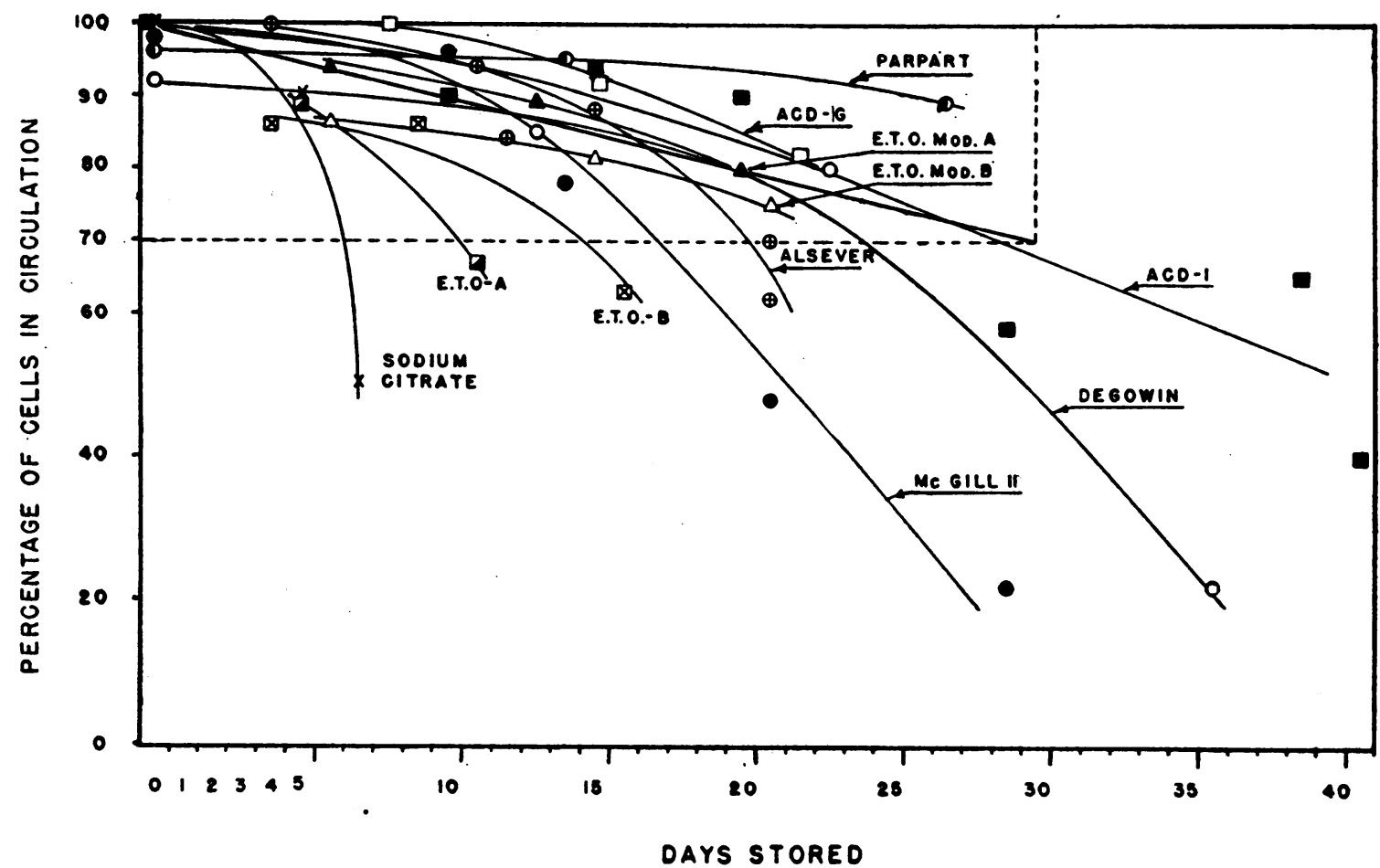

Fig. 1. Post-Transfusion Survival of Human Erythrocytes Stored as Whole Blood at $4^{\circ}$ C.

In Figures 1, 2 and 3, the solid line represents the normal death rate of live red cells in circulation, approximating one per cent per day. The "zone of safe transfusion" within which 70 per cent or more of the transfused cells are viable is indicated by the broken line rectangle.

Symbols refer to the following solutions :

$$
\begin{aligned}
\boldsymbol{x} & =\text { Sodium citrate } \\
\mathbf{0} & =\text { De Gowin's solution } \\
\mathbf{D} & =\text { Parpart's solution } \\
\boldsymbol{\Phi} & =\text { McGill solution } \\
\boldsymbol{\Phi} & =\text { Alsever's solution } \\
\boldsymbol{D} & =\text { ACD-1 } \\
\boldsymbol{D} & =\text { ACD-G } \\
\boldsymbol{\Delta} & =\text { E.T.O. citrate } \\
\boldsymbol{\Delta} & =\text { E.T.O. citrate-saline } \\
\boldsymbol{\Delta} & =\text { E.T.Odification A }
\end{aligned}
$$


TABLE II

Post-transfusion survival of human erythrocytes drawn as whole blood and stored at $4^{\circ} \mathrm{C}$.

\begin{tabular}{|c|c|c|c|c|c|c|c|c|c|c|c|}
\hline \multirow{2}{*}{ Solution } & \multirow{2}{*}{$\begin{array}{l}\text { Trans- } \\
\text { fusion } \\
\text { no. }\end{array}$} & \multirow{2}{*}{$\begin{array}{l}\text { Days } \\
\text { stored }\end{array}$} & \multicolumn{2}{|c|}{ Blood group } & \multicolumn{2}{|c|}{$\begin{array}{c}\text { Transfused } \\
\text { volume }\end{array}$} & \multicolumn{2}{|c|}{$\begin{array}{l}\text { Age of tagged } \\
\text { cells }\end{array}$} & \multirow{2}{*}{ Clots } & \multirow{2}{*}{$\begin{array}{c}\text { Reac- } \\
\text { tions } \\
\text { (pyrogen) }\end{array}$} & \multirow{2}{*}{ Survival } \\
\hline & & & Donor & Recip. & Total & Cells & $\mathrm{Fe}^{56}$ & $\mathrm{Fe}^{50}$ & & & \\
\hline $\begin{array}{l}4 \text { per cent sodium } \\
\text { citrate } \\
\text { (1) }\end{array}$ & $\begin{array}{l}\text { A } \\
\text { B } \\
\text { C } \\
\text { D } \\
22 \\
23 \\
24\end{array}$ & $\begin{array}{l}0 \\
0 \\
7 \\
8 \\
1 \\
5 \\
8\end{array}$ & $\begin{array}{l}0 \\
0 \\
0 \\
0 \\
0 \\
0 \\
0\end{array}$ & $\begin{array}{l}0 \\
0 \\
0 \\
0 \\
0 \\
0 \\
0\end{array}$ & $\begin{array}{c}m l . \\
337 \\
335 \\
250 \\
268 \\
112 \\
100 \\
101\end{array}$ & $\begin{array}{r}m l . \\
142 \\
132 \\
108 \\
116 \\
43 \\
40 \\
40\end{array}$ & $\begin{array}{l}\text { days } \\
146 \\
153 \\
143 \\
143 \\
121 \\
121 \\
121\end{array}$ & $\begin{array}{l}\text { days } \\
\\
\\
24 \\
24 \\
24\end{array}$ & $\begin{array}{l}++ \\
++ \\
++ \\
++ \\
+ \\
++ \\
++\end{array}$ & $\begin{array}{l}0 \\
0 \\
0 \\
0 \\
0 \\
0 \\
0\end{array}$ & $\begin{array}{c}\text { per cent } \\
100 \\
52 \\
50 \\
51 \\
100 \\
90 \\
51\end{array}$ \\
\hline $\begin{array}{l}\text { McGill } \\
\text { (2) }\end{array}$ & $\begin{array}{l}1 \\
2 \\
3 \\
4 \\
5\end{array}$ & $\begin{array}{r}0 \\
10 \\
14 \\
21 \\
29\end{array}$ & $\begin{array}{l}0 \\
0 \\
0 \\
0 \\
0\end{array}$ & $\begin{array}{l}0 \\
0 \\
0 \\
0 \\
0\end{array}$ & $\begin{array}{l}157 \\
142 \\
117 \\
137 \\
143\end{array}$ & $\begin{array}{l}50 \\
42 \\
36 \\
43 \\
46\end{array}$ & $\begin{array}{l}28 \\
28 \\
28 \\
28 \\
28\end{array}$ & $\cdot$ & $\begin{array}{c}+ \\
++ \\
+t \\
+t \\
+t\end{array}$ & $\begin{array}{l}0 \\
0 \\
0 \\
0 \\
+\end{array}$ & $\begin{array}{l}98 \\
96 \\
78 \\
48 \\
22\end{array}$ \\
\hline $\begin{array}{l}\text { DeGowin's } \\
\text { (3) }\end{array}$ & $\begin{array}{l}18 \\
19 \\
20 \\
21\end{array}$ & $\begin{array}{r}0 \\
13 \\
23 \\
36\end{array}$ & $\begin{array}{l}0 \\
0 \\
0 \\
0\end{array}$ & $\begin{array}{l}0 \\
0 \\
0 \\
0\end{array}$ & $\begin{array}{l}157 \\
166 \\
141 \\
153\end{array}$ & $\begin{array}{l}40 \\
41 \\
39 \\
30\end{array}$ & $\begin{array}{l}50 \\
50 \\
50 \\
50\end{array}$ & & & $\begin{array}{l}0 \\
+ \\
0 \\
0\end{array}$ & $\begin{array}{l}92 \\
85 \\
80 \\
22\end{array}$ \\
\hline $\begin{array}{l}\text { Alsever's } \\
\text { (4) }\end{array}$ & $\begin{array}{l}51 \\
53 \\
55 \\
57 \\
59 \\
61\end{array}$ & $\begin{array}{r}4 \\
12 \\
21 \\
11 \\
15 \\
21\end{array}$ & $\begin{array}{l}0 \\
0 \\
0 \\
0 \\
0 \\
0\end{array}$ & $\begin{array}{c}\text { A } \\
0 \\
A \\
A \\
A \\
0\end{array}$ & $\begin{array}{l}197 \\
178 \\
183 \\
175 \\
172 \\
175\end{array}$ & $\begin{array}{l}47 \\
44 \\
49 \\
47 \\
47 \\
49\end{array}$ & $\begin{array}{l}83 \\
83 \\
83 \\
37 \\
37 \\
37\end{array}$ & & $\begin{array}{c}0 \\
+ \\
++ \\
+ \\
++ \\
++\end{array}$ & $\begin{array}{l}0 \\
0 \\
0 \\
0 \\
+ \\
0\end{array}$ & $\begin{array}{r}100 \\
84 \\
70 \\
94 \\
88 \\
62\end{array}$ \\
\hline $\begin{array}{l}\text { Parpart's } \\
\text { (5) }\end{array}$ & $\begin{array}{l}25 \\
26 \\
27\end{array}$ & $\begin{array}{r}0 \\
14 \\
27\end{array}$ & $\begin{array}{l}0 \\
0 \\
0\end{array}$ & $\begin{array}{l}0 \\
0 \\
0\end{array}$ & $\begin{array}{l}120 \\
118 \\
126\end{array}$ & $\begin{array}{l}34 \\
33 \\
39\end{array}$ & $\begin{array}{l}65 \\
65 \\
65\end{array}$ & & $\begin{array}{l}0 \\
++ \\
++\end{array}$ & $\begin{array}{l}0 \\
0 \\
0\end{array}$ & $\begin{array}{l}96 \\
95 \\
89\end{array}$ \\
\hline$\underset{(6)}{A C D-1}$ & $\begin{array}{l}10 \\
11 \\
12 \\
13 \\
32 \\
33 \\
34 \\
56 \\
58 \\
60\end{array}$ & $\begin{array}{r}2 \\
11 \\
20 \\
39 \\
15 \\
29 \\
41 \\
11 \\
15 \\
21\end{array}$ & $\begin{array}{l}0 \\
0 \\
0 \\
0 \\
0 \\
0 \\
0 \\
0 \\
0 \\
0\end{array}$ & $\begin{array}{l}\mathbf{0} \\
0 \\
\mathbf{0} \\
\mathbf{0} \\
\mathbf{0} \\
\mathbf{0} \\
\mathbf{0} \\
\mathbf{A} \\
\mathbf{A} \\
\mathrm{A}\end{array}$ & $\begin{array}{r}84 \\
71 \\
77 \\
82 \\
132 \\
128 \\
128 \\
93 \\
105 \\
105\end{array}$ & $\begin{array}{l}37 \\
31 \\
35 \\
37 \\
51 \\
55 \\
51 \\
42 \\
48 \\
48\end{array}$ & $\begin{array}{r}24 \\
24 \\
24 \\
24 \\
133 \\
133 \\
133 \\
37 \\
37 \\
37\end{array}$ & $\begin{array}{l}31 \\
45 \\
57\end{array}$ & $\begin{array}{l}+ \\
+ \\
+ \\
+\end{array}$ & $\begin{array}{l}0 \\
0 \\
0 \\
0 \\
0 \\
0 \\
0 \\
0 \\
0 \\
0\end{array}$ & $\begin{array}{r}100 \\
90 \\
90 \\
65 \\
94 \\
58 \\
40 \\
99 \\
94 \\
81\end{array}$ \\
\hline$\underset{(7)}{\operatorname{ACD}-G}$ & $\begin{array}{l}159 \\
161 \\
163 \\
165 \\
167 \\
169\end{array}$ & $\begin{array}{r}8 \\
15 \\
22 \\
12 \\
19 \\
27\end{array}$ & $\begin{array}{l}0 \\
0 \\
0 \\
0 \\
0 \\
0\end{array}$ & $\begin{array}{l}\text { B } \\
0 \\
0 \\
0 \\
0 \\
0\end{array}$ & $\begin{array}{l}269 \\
249 \\
268 \\
545 \\
546 \\
459\end{array}$ & $\begin{array}{l}115 \\
110 \\
129 \\
286 \\
230 \\
230\end{array}$ & $\begin{array}{r}98 \\
164 \\
98 \\
135 \\
394 \\
393\end{array}$ & & $\begin{array}{c}0 \\
++ \\
+ \\
+ \\
++ \\
++\end{array}$ & $\begin{array}{l}0 \\
0 \\
0 \\
0 \\
0 \\
0\end{array}$ & $\begin{array}{r}100 \\
92 \\
82 \\
95 \\
92 \\
62\end{array}$ \\
\hline $\begin{array}{l}\text { E.T.O. } 4 \text { per cent } \\
\text { citrate } \\
(8)\end{array}$ & $\begin{array}{l}101 \\
103 \\
113\end{array}$ & $\begin{array}{r}4 \\
9 \\
14\end{array}$ & $\begin{array}{l}\mathbf{0} \\
\mathrm{A} \\
\mathbf{0}\end{array}$ & $\begin{array}{l}\mathbf{0} \\
\mathrm{A} \\
\mathrm{A}\end{array}$ & $\begin{array}{l}610 \\
595 \\
540\end{array}$ & $\begin{array}{l}232 \\
247 \\
205\end{array}$ & $\begin{array}{l}138 \\
138 \\
265\end{array}$ & & $\begin{array}{l}+t \\
+t \\
++\end{array}$ & $\begin{array}{l}\mathbf{0} \\
0 \\
0\end{array}$ & $\begin{array}{l}86 \\
86 \\
66\end{array}$ \\
\hline $\begin{array}{l}\text { E.T.O. } 2.5 \text { per cent } \\
\text { citrate (9) }\end{array}$ & $\begin{array}{l}102 \\
114\end{array}$ & $\begin{array}{r}4 \\
15\end{array}$ & $\begin{array}{l}\mathbf{0} \\
\mathbf{0}\end{array}$ & $\begin{array}{l}\mathbf{0} \\
\mathbf{0}\end{array}$ & $\begin{array}{l}595 \\
425\end{array}$ & $\begin{array}{l}209 \\
181\end{array}$ & $\begin{array}{l}144 \\
208\end{array}$ & & $\stackrel{++}{++}$ & $\begin{array}{l}\mathbf{0} \\
\mathbf{0}\end{array}$ & $\begin{array}{r}89 \\
6\end{array}$ \\
\hline $\begin{array}{l}\text { E.T.O. } \\
\text { Mod. A } \\
\text { (10) }\end{array}$ & $\begin{array}{l}95 \\
97 \\
99\end{array}$ & $\begin{array}{r}6 \\
13 \\
20\end{array}$ & $\begin{array}{l}\text { A } \\
\text { A } \\
\text { A }\end{array}$ & $\begin{array}{l}\text { A } \\
\text { A } \\
\text { A }\end{array}$ & $\begin{array}{l}595 \\
545 \\
320\end{array}$ & $\begin{array}{l}228 \\
213 \\
122\end{array}$ & $\begin{array}{r}86 \\
118 \\
116\end{array}$ & & $\stackrel{+}{+}+$ & $\begin{array}{l}0 \\
0 \\
0\end{array}$ & $\begin{array}{l}94 \\
89 \\
80\end{array}$ \\
\hline $\begin{array}{c}\text { E.T.O. } \\
\text { Mod. B }\end{array}$ & $\begin{array}{r}96 \\
98 \\
100\end{array}$ & $\begin{array}{r}7 \\
14 \\
21\end{array}$ & $\begin{array}{l}\text { A } \\
\text { A } \\
\text { A }\end{array}$ & $\begin{array}{l}\text { A } \\
\text { A } \\
\text { A }\end{array}$ & $\begin{array}{l}535 \\
515 \\
300\end{array}$ & $\begin{array}{l}202 \\
186 \\
120\end{array}$ & $\begin{array}{l}121 \\
120 \\
119\end{array}$ & & $\stackrel{+}{+}+$ & $\begin{array}{l}0 \\
0 \\
0\end{array}$ & $\begin{array}{l}86 \\
90 \\
75\end{array}$ \\
\hline
\end{tabular}


tion B. After the addition of the stock solution, it was still possible to draw about $480 \mathrm{ml}$. of blood into the bottle without re-evacuation. The bloods in Modification A were transfused after 6,13 , and 20 days of storage, and those in Modification B after 7, 14, and 21 days of storage.

The post-transfusion survival of erythrocytes, preserved as whole blood as described above, is given in Table III and Figure 1.

\section{Experiments on preservative solutions for resuspending red cells after removal of plasma}

The composition of the resuspension fluids studied is given in Table I. Except as noted, all red cell resuspensions were from whole blood drawn by gravity into 4 per cent sodium citrate at a 10 to 1 ratio. Bottles were centrifuged at 1,900 r.p.m. for 30 minutes. The quantity of resuspension fluid added to the packed red cells was approximately equal to the amount of plasma removed, except in the case of the modified acid citrate (Washington Conference-Experiments Nos. 120 through 123).

Two types of fluids were used: (1) solutions of electrolytes with and without dextrose, and (2) electrolytedextrose solutions to which human serum protein fractions had been added. All donors were blood group $\mathrm{O}$.

\section{Electrolyte solutions}

(12) ISOTONIC (0.85 PER CENT) SODIUM CHLORIDE. OPEN BURETTE METHOD

Experiments Nos. 6 through 8. Five hundred $\mathrm{ml}$. of citrated blood were centrifuged, and the cells were resuspended in 0.85 per cent sodium chloride, within 2 hours of the time of collection. All procedures were carried out at room temperature. This cell resuspension was divided into 3 equal portions and transfused after 0,3 , and 10 days' storage.

(13) TEN PER CENT CORN SYRUP. OPEN BURETTE METHOD

Experiments Nos. 14 through 17. The corn syrup used was supplied by Dr. Thalhimer ${ }^{6}$ (46). Three hundred fifty $\mathrm{ml}$. of whole blood were drawn into $35 \mathrm{ml}$. of 3.2 per cent sodium citrate and centrifuged in a refrigerated centrifuge. The plasma was removed, and an equal volume of corn syrup was added to the cells, within 2 hours of the time of blood collection. The entire procedure was carried out at not over $10^{\circ} \mathrm{C}$. After thorough mixing, the cell resuspension was divided into 4 equal aliquots, and these were transfused after storage at $4^{\circ} \mathrm{C}$. for $0,5,12$, and 21 days.

6 The composition is said to be as follows :

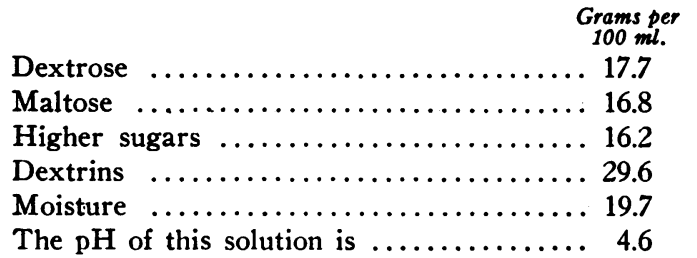

\section{STORAGE BOTTLE METHOD}

Experiments Nos. 140 through 147. A more extensive series of experiments was conducted in collaboration with Dr. Thalhimer and Lt. H. Blake, M.C., U.S.N.R. Full bleedings were taken by gravity from each of 8 donors, the plasma was removed, and the cells were resuspended in chilled 10 per cent corn syrup within 24 hours of collection. The bottles were shipped in a portable refrigerator by truck to New York City. They were stored in the refrigerator of the New York Red Cross Blood Donor Center. These cell resuspensions were transfused into selected patients on the wards of the New York Hospital at $9,11,12,13,14,15,18$, and 20 days after drawing.

(14) PHOSPHATE-BUFFERED CITRATE-DEXTROSE SOLUTION, PH 6.8 (HUGHES). OPEN BURETTE METHOD

Experiments Nos. 28 through 31. The red cells from 320 $\mathrm{ml}$. of whole citrated blood were resuspended, at room temperature, at about 20 hours after the blood was drawn. After thorough mixing, the entire cell resuspension was divided into 4 approximately equal aliquots, which were transfused after storage for $2,6,11$, and 20 days.

(15) PHOSPhATE-BUfFERED DEXTROSE SOLUTION. PH 6.0 (HUGHES). OPEN BURETTE METHOD

Experiments Nos. 42 through 45. The donor from whom this blood was drawn received the first injection of $\mathrm{Fe}^{\mathrm{ss}} 133$ days and his last injection of $\mathrm{Fe}^{\mathrm{ss}} 95$ days prior to the bleeding for this experiment. His first and last injections of $\mathrm{Fe}^{\mathrm{w0}}$ were 16 and 5 days, respectively, prior to bleeding.

Five hundred $\mathrm{ml}$. of blood were collected into $125 \mathrm{ml}$. of ACD-1 at room temperature. This was stored for about 40 hours at $4^{\circ} \mathrm{C}$., and the cells were then resuspended. This cell resuspension was divided into 4 approximately equal aliquots, which were transfused at 3 , 10,16 , and 30 days of storage.

(16) Citrate-BUfFERED CITRATE-DEXTROSE SOLUTION, PH 5.0 (HUGHes). STORAGE BOTTLE METHOD. (This series was for a direct comparison with 10 per cent corn syrup, Experiments Nos. 140 through 147)

Experiments Nos. 132 through 139. The red cells from eight $500-\mathrm{ml}$. bleedings were resuspended in the chilled solution about 24 hours after collection. The bottles were shipped to New York in the same portable refrigerator used for the cells resuspended in 10 per cent corn syrup (Experiments Nos. 140 through 147), and stored under identical conditions. These resuspensions were transfused into ward patients at the New York Hospital after $10,11,13,14,15$ (2), 18, and 20 days after drawing.

(17) CITRATE-BUfFEREd CITRATE-DEXTROSE SOLUTION, PH 3.8 (hUGHES). COLLECTING BOtTLE METHOD

Experiments Nos. 89, 91, 93, 105, 107. Three full bleedings were taken from each of 3 donors, the cells were resuspended in the chilled solution within 24 hours 
and transfused after 10,18 and 22 days of storage. One full bleeding from a fourth donor was resuspended, mixed, and subdivided into 2 aliquots which were transfused after 32 and 39 days of storage.

Experiments Nos. 109 through 112. Five hundred $\mathrm{ml}$. of blood, drawn in equal amounts into 2 collecting bottles, were taken from 2 donors, and the cells were resuspended in the collecting bottles within $2 \frac{1}{2}$ hours from the time of bleeding. The solution was at room temperature. Two aliquots from one donor were transfused after 8 and 21 days, and the aliquots from the other donor after 15 and 28 days of storage.

\section{(18 AND 19) MODIFIED ACD (RAPOPORT $C_{2} A, C_{2} A^{1}$ ). OPEN} BURETTE METHOD

Experiments Nos. 46 through 49. Five hundred $\mathrm{ml}$. of citrated blood from 1 donor were divided into 2 equal aliquots. Each of these was in turn divided into 2 equal aliquots, centrifuged, and the cells resuspended, 2 in $\mathrm{C}_{2} \mathrm{~A}$ and two in $C_{2} A^{1}$. The aliquots resuspended in $C_{2} A$ were transfused after 13 and 20 days, and those resuspended in $\mathrm{C}_{2} \mathrm{~A}^{1}$ were transfused after 13 and 22 days of storage.

(20) MOdFIEd aCid Citrate.' STORAGE bottle method

Experiments Nos. 120 through 123. Five hundred $\mathrm{ml}$. of blood were taken by gravity from 2 donors into sodium citrate. The blood from each donor was drawn into 2 Fenwal collecting bottles, so that each bottle contained $250 \mathrm{ml}$. of blood. Within 24 hours from the time of collection, the cells in each bottle were resuspended in only $50 \mathrm{ml}$. of the solution, which was pre-chilled. These resuspensions were transfused after $6,10,16$, and 21 days of storage. The tagged cells in the 6 - and 10-day stored resuspension were no more than' 46 days old, while those in the 16- and 21-day stored resuspensions were of mixed age, on the day of transfusion.

(21) BICARBONATE-BUFFERED CITRATE-DEXTROSE, PH 6.5 (HUGHES). STORAGE BOTTLE METHOD

Experiments Nos. 155 through 158. Five hundred $\mathrm{ml}$. of whole blood were taken from each of 2 donors into 125 ml. of ACD-1. About 20 hours after collection, bloods were centrifuged and plasma removed in the usual manner, the packed cells being refrigerated for 4 hours. Three hundred $\mathrm{ml}$. of chilled diluent were then added to each, by siphonage (to prevent escape of $\mathrm{CO}_{2}$ ). Each cell resuspension was then divided into 2 aliquots, by gentle suction. The aliquots were transfused after 6,13 , and 21 days of storage at $4^{\circ} \mathrm{C}$.

The results of these experiments are summarized in Table III and Figure 2.

(22) PACKED CELLS FROM WHOLE BLOOD IN ACD-1. STORAGE BOTTLE METHOD

Experiments Nos. 115 through 119. Five hundred $\mathrm{ml}$. of blood were taken from each of 5 donors into $125 \mathrm{ml}$.

\footnotetext{
7 Solution recommended for trial at Conference on $\mathrm{Re}$ suspended Blood Cells, of C.M.R., at Washington, D. C., $5 / 18 / 45$.
}

of cold ACD-1 by gravity. After 24 hours of refrigeration, the bottles were centrifuged, the plasma removed, and the bottles placed in storage. The packed cells were transfused after storage for 9, 14, 15, 16, and 21 days. The cells stored 15 days (No 115) were transfused as packed cells, without the addition of saline. In the other 4 experiments, $125 \mathrm{ml}$. of sterile normal saline were added $1 / 2$ hour before the blood was transfused. The cells were thoroughly mixed with the diluent before administration.

\section{(23) PACKed Cells in ACD-G. COLleCtiNG Bottle METHOD}

Experiments Nos. 160, 162, 164. No added diluent. Five hundred $\mathrm{ml}$. of blood were taken by gravity from 1 donor, and subdivided as in Experiments Nos. 159, 161, and 163, [see (7) above]. The collecting bottles were centrifuged, the plasma was withdrawn, and the packed cells were transfused after 7,14 , and 21 days of storage, without the addition of any diluent.

Experiments Nos. 166, 168, 170. Diluent added at time of transfusion. Five hundred $\mathrm{ml}$. of blood were taken from each of 3 donors. The collecting bottles were centrifuged, the plasma was withdrawn, and the packed cells were transfused after 12,19 , and 27 days of storage. One hundred twenty-five $\mathrm{ml}$. of 0.85 per cent $\mathrm{NaCl}$ were added just prior to transfusion.

Experiments Nos. 176 and 175. 0.86 per cent $\mathrm{NaCl}+$ 0.5 per cent dextrose. Two hundred fifty $\mathrm{ml}$. of blood were taken from each of 2 donors. One hundred $\mathrm{ml}$. of diluent were added. The resuspensions were transfused after storage for 14 and 20 days. Hematocrits were $\mathbf{5 0 . 5}$ and 56.4. Survival was 95 and 84 per cent.

Experiments Nos. 171 and 172. 1.0 per cent $\mathrm{NaCl}$. Two hundred fifty $\mathrm{ml}$. of blood were taken from each of 2 donors. One hundred $\mathrm{ml}$. of diluent were added. The resuspensions were transfused after storage for 13 and 21 days. Hematocrits were 47 and 50. Survival was 100 and 86 per cent.

Experiments Nos. 173 and 174. 1.0 per cent $\mathrm{NaCl}+$ 0.5 per cent dextrose. Two hundred fifty $\mathrm{ml}$. of blood were taken from each of 2 donors. One hundred $\mathrm{ml}$. of diluent were added. The resuspensions were transfused after 14 and 20 days of storage. Hematocrits were 48 in both instances. Survival was 100 and 73 per cent.

Experiments Nos. 178 and 177. 10 per cent corn syrup. Two hundred fifty $\mathrm{ml}$. of whole blood were taken from each of 2 donors. One hundred $\mathrm{ml}$. of diluent were added. The resuspensions were transfused after 14 and 21 days of storage. Hematocrits were 53.5 and 64.5. Survival was 64 and 81 per cent.

Experiments Nos. 180 and 181. Stored with diluent added. 1.1 per cent $\mathrm{NaCl}+0.5$ per cent dextrose. Two hundred fifty $\mathrm{ml}$. of blood were taken into each of 2 bottles from the same donor. One hundred $\mathrm{ml}$. of diluent were added immediately after removal of plasma. The resuspensions were transfused after 12 and 19 days of storage.

Experiments Nos. 182 and 183. Stored with diluent added. 0.85 per cent $\mathrm{NaCl}+0.5$ per cent dextrose. Two 
TABLE III

Post-transfusion survival of human erythrocytes drawn as whole blood in 4 per cent sodium citrate and stored after resuspension in electrolyte solutions at $4^{\circ} \mathrm{C}$

\begin{tabular}{|c|c|c|c|c|c|c|c|c|c|c|}
\hline \multirow{2}{*}{ Resuspension solution } & \multirow{2}{*}{$\begin{array}{l}\text { Trans- } \\
\text { fusion } \\
\text { no. }\end{array}$} & \multirow{2}{*}{$\begin{array}{l}\text { Days } \\
\text { stored }\end{array}$} & \multirow{2}{*}{$\begin{array}{l}\text { Recip. } \\
\text { blood } \\
\text { group }\end{array}$} & \multicolumn{2}{|c|}{$\begin{array}{l}\text { Transfused } \\
\text { volume }\end{array}$} & \multicolumn{2}{|c|}{$\begin{array}{l}\text { Age of tagged } \\
\text { cells* }\end{array}$} & \multirow{2}{*}{ Clots } & \multirow{2}{*}{$\begin{array}{l}\text { Reac- } \\
\text { tions }\end{array}$} & \multirow{2}{*}{ Survival } \\
\hline & & & & Total & Cells & $\mathrm{Fe}^{\mathrm{ss}}$ & $\mathrm{Fe}^{\mathrm{bo}}$ & & & \\
\hline $\begin{array}{l}0.85 \text { per cent sodium } \\
\text { chloride } \\
\text { (12) }\end{array}$ & $\begin{array}{l}6 \\
7 \\
8\end{array}$ & $\begin{array}{r}0 \\
3 \\
10\end{array}$ & $\begin{array}{l}\mathbf{0} \\
\mathbf{0} \\
\mathbf{0}\end{array}$ & $\begin{array}{l}m l . \\
175 \\
160 \\
140\end{array}$ & $\begin{array}{c}m l . \\
68 \\
68 \\
64\end{array}$ & $\begin{array}{r}\text { days } \\
40 \\
\cdot 40 \\
40\end{array}$ & days & $\begin{array}{c}0 \\
+++ \\
++++\end{array}$ & $\begin{array}{l}\mathbf{0} \\
0 \\
0\end{array}$ & $\begin{array}{c}\text { per cent } \\
92 \\
90 \\
8\end{array}$ \\
\hline $\begin{array}{l}10 \text { per cent corn syrup } \\
\text { (13) }\end{array}$ & $\begin{array}{r}14 \\
15 \\
16 \\
17 \\
140 \\
141 \\
142 \\
143 \\
144 \\
145 \\
146 \\
147\end{array}$ & $\begin{array}{r}0 \\
5 \\
12 \\
21 \\
9 \\
13 \\
15 \\
20 \\
11 \\
12 \\
14 \\
18\end{array}$ & $\begin{array}{l}0 \\
0 \\
0 \\
0 \\
0 \\
\mathrm{~A} \\
\mathrm{~A} \\
\mathrm{~A} \\
0 \\
\mathrm{~A} \\
\mathrm{~A} \\
0\end{array}$ & $\begin{array}{r}59 \\
57 \\
62 \\
97 \\
502 \\
487 \\
475 \\
470 \\
479 \\
480 \\
520 \\
425\end{array}$ & $\begin{array}{r}31 \\
19 \\
20 \\
32 \\
227 \\
169 \\
178 \\
193 \\
189 \\
173 \\
220 \\
164\end{array}$ & $\begin{array}{r}24 \\
24 \\
24 \\
24 \\
9 \\
9 \\
11 \\
11 \\
8 \\
12 \\
10 \\
10\end{array}$ & & $\begin{array}{c}0 \\
+ \\
+ \\
++ \\
+ \\
+ \\
+ \\
0 \\
+ \\
+ \\
+ \\
0\end{array}$ & $\begin{array}{l}0 \\
0 \\
0 \\
0 \\
+ \\
0 \\
0 \\
0 \\
0 \\
0 \\
0 \\
0\end{array}$ & $\begin{array}{r}100 \\
60 \\
42 \\
17 \\
95 \\
94 \\
41 \\
45 \\
92 \\
78 \\
60 \\
58\end{array}$ \\
\hline $\begin{array}{c}\text { Phosphate-buffered } \\
\text { citrate-dextrose } \\
\text { pH 6.8 } \\
\text { (14) }\end{array}$ & $\begin{array}{l}28 \\
29 \\
30 \\
31\end{array}$ & $\begin{array}{r}2 \\
6 \\
11 \\
20\end{array}$ & $\begin{array}{l}0 \\
0 \\
0 \\
0\end{array}$ & $\begin{array}{l}74 \\
60 \\
67 \\
64\end{array}$ & $\begin{array}{l}30 \\
24 \\
26 \\
23\end{array}$ & $\begin{array}{l}88 \\
88 \\
88 \\
88\end{array}$ & & $\begin{array}{l}+ \\
+ \\
+\end{array}$ & $\begin{array}{l}+ \\
0 \\
0 \\
0\end{array}$ & $\begin{array}{l}98 \\
97 \\
88 \\
86\end{array}$ \\
\hline $\begin{array}{c}\text { Phosphate-buffered } \\
\text { citrate-dextrose } \\
\text { pH 6.0 } \\
\text { (15) }\end{array}$ & $\begin{array}{l}42 \\
43 \\
44 \\
45\end{array}$ & $\begin{array}{r}3 \\
10 \\
16 \\
30\end{array}$ & $\begin{array}{l}\text { 0 } \\
\text { A } \\
\text { A } \\
\text { A }\end{array}$ & $\begin{array}{l}134 \\
137 \\
131 \\
117\end{array}$ & $\begin{array}{l}58 \\
58 \\
56 \\
50\end{array}$ & $\begin{array}{l}133 \\
133 \\
133 \\
133\end{array}$ & $\begin{array}{l}28 \\
28 \\
28 \\
28\end{array}$ & $\begin{array}{c}+ \\
+ \\
+ \\
+\end{array}$ & $\begin{array}{l}\mathbf{0} \\
0 \\
0 \\
+\end{array}$ & $\begin{array}{l}90 \\
94 \\
80 \\
45\end{array}$ \\
\hline $\begin{array}{c}\text { Citrate-buffered } \\
\text { citrate-dextrose } \\
\text { pH 5.0 (Hughes) } \\
\text { (16) }\end{array}$ & $\begin{array}{l}132 \\
133 \\
134 \\
135 \\
136 \\
137 \\
138 \\
139\end{array}$ & $\begin{array}{l}10 \\
13 \\
15 \\
20 \\
11 \\
14 \\
15 \\
18\end{array}$ & $\begin{array}{l}\text { B } \\
0 \\
0 \\
\mathrm{~A} \\
\mathbf{0} \\
\mathbf{0} \\
\mathrm{A} \\
\mathrm{A}\end{array}$ & $\begin{array}{l}503 \\
467 \\
520 \\
315 \\
510 \\
500 \\
492 \\
357\end{array}$ & $\begin{array}{l}232 \\
217 \\
235 \\
147 \\
256 \\
234 \\
245 \\
175\end{array}$ & $\begin{array}{r}341 \\
8 \\
343 \\
403 \\
10 \\
10 \\
10 \\
0\end{array}$ & & $\begin{array}{c}+ \\
0 \\
0 \\
++ \\
0 \\
0 \\
+ \\
++\end{array}$ & $\begin{array}{c}0 \\
0 \\
0 \\
0 \\
0 \\
0 \\
0 \\
++\end{array}$ & $\begin{array}{l}93 \\
70 \\
82 \\
72 \\
54 \\
40 \\
74 \\
31\end{array}$ \\
\hline $\begin{array}{c}\text { Citrate-buffered } \\
\text { citrate-dextrose } \\
\mathrm{pH} 5.8 \text { (Hughes) } \\
\text { (17) }\end{array}$ & $\begin{array}{r}89 \\
91 \\
93 \\
105 \\
107 \\
109 \\
110 \\
111 \\
112\end{array}$ & $\begin{array}{r}10 \\
18 \\
22 \\
31 \\
38 \\
8 \\
15 \\
21 \\
28\end{array}$ & $\begin{array}{l}\mathbf{0} \\
\mathbf{0} \\
\mathbf{0} \\
\mathbf{B} \\
\mathbf{0} \\
\mathbf{B} \\
\mathbf{0} \\
\mathbf{0} \\
\mathbf{0}\end{array}$ & $\begin{array}{l}472 \\
420 \\
300 \\
200 \\
165 \\
260 \\
270 \\
272 \\
237\end{array}$ & $\begin{array}{r}182 \\
191 \\
137 \\
96 \\
81 \\
120 \\
130 \\
129 \\
109\end{array}$ & $\begin{array}{l}179 \\
104 \\
107 \\
251 \\
251 \\
237 \\
160 \\
237 \\
160\end{array}$ & & $\begin{array}{l}+ \\
+ \\
+ \\
+ \\
+ \\
+ \\
+ \\
+ \\
+\end{array}$ & $\begin{array}{l}+ \\
0 \\
0 \\
0 \\
0 \\
0 \\
+ \\
0 \\
0\end{array}$ & $\begin{array}{r}87 \\
85 \\
80 \\
45 \\
0 \\
92 \\
85 \\
76 \\
27\end{array}$ \\
\hline $\begin{array}{c}\text { Mod. ACD (Rapoport) } \\
\mathrm{C}_{2} \mathrm{~A}, \mathrm{pH} 5 \text { (18) }\end{array}$ & $\begin{array}{l}46 \\
47\end{array}$ & $\begin{array}{l}13 \\
20\end{array}$ & A & $\begin{array}{r}142 \\
92\end{array}$ & $\begin{array}{l}46 \\
42\end{array}$ & $\begin{array}{l}216 \\
216\end{array}$ & & + & $\stackrel{+}{+}$ & $\begin{array}{l}83 \\
62\end{array}$ \\
\hline $\begin{array}{c}\text { Mod. ACD (Rapoport) } \\
\mathrm{C}_{2} \mathrm{~A}^{1}, \mathrm{pH} 5.5 \text { (19) }\end{array}$ & $\begin{array}{l}48 \\
49\end{array}$ & $\begin{array}{l}13 \\
22\end{array}$ & $\begin{array}{l}\mathrm{A} \\
\mathrm{A}\end{array}$ & $\begin{array}{l}107 \\
107\end{array}$ & $\begin{array}{l}50 \\
50\end{array}$ & $\begin{array}{l}216 \\
216\end{array}$ & & $\stackrel{+}{+}$ & + & $\begin{array}{l}90 \\
69\end{array}$ \\
\hline $\begin{array}{c}\text { Mod. ACD } \\
\text { (Washington Conf.) } \\
\text { (20) }\end{array}$ & $\begin{array}{l}120 \\
121 \\
122 \\
123\end{array}$ & $\begin{array}{r}6 \\
10 \\
16 \\
21\end{array}$ & $\begin{array}{l}\mathbf{0} \\
\mathrm{A} \\
\mathrm{A} \\
\mathbf{0}\end{array}$ & $\begin{array}{l}157 \\
160 \\
138 \\
113\end{array}$ & $\begin{array}{r}104 \\
106 \\
94 \\
49\end{array}$ & $\begin{array}{r}36 \\
36 \\
231 \\
231\end{array}$ & & $\begin{array}{l}+ \\
+ \\
+\end{array}$ & $\begin{array}{l}0 \\
0 \\
0 \\
0\end{array}$ & $\begin{array}{l}94 \\
80 \\
58 \\
32\end{array}$ \\
\hline $\begin{array}{l}\text { Bicarbonate-buffered } \\
\text { citrate-dextrose } \\
(21)\end{array}$ & $\begin{array}{l}155 \\
156 \\
157 \\
158\end{array}$ & $\begin{array}{r}6 \\
13 \\
19 \\
28\end{array}$ & $\begin{array}{l}\mathbf{0} \\
\mathrm{A} \\
\mathbf{0} \\
\mathbf{0}\end{array}$ & $\begin{array}{l}259 \\
273 \\
246 \\
256\end{array}$ & $\begin{array}{l}100 \\
115 \\
100 \\
109\end{array}$ & $\begin{array}{l}337 \\
337 \\
337 \\
337\end{array}$ & & $\begin{array}{l}+ \\
+ \\
+\end{array}$ & $\begin{array}{l}\mathbf{0} \\
0 \\
0 \\
0\end{array}$ & $\begin{array}{l}90 \\
89 \\
71 \\
46\end{array}$ \\
\hline
\end{tabular}

* Days between last injection of radioactive iron and day of bleeding. 
hundred fifty $\mathrm{ml}$. of blood were taken into each of 2 bottles from the same donor. One hundred $\mathrm{ml}$. of diluent were added immediately after removal of plasma. The resuspensions were transfused after 13 and 20 days of storage.

Experiments Nos. 184 and 185. Stored with diluent added. 0.6 per cent $\mathrm{NaCl}+0.5$ per cent dextrose. Two hundred fifty $\mathrm{ml}$. of blood were taken into each of 2 bottles from the same donor. One hundred $\mathrm{ml}$. of diluent were added immediately after removal of plasma. The resuspensions were transfused after 13 and 20 days of storage.

Experiments Nos. 186 and 187. Stored with diluent added. 0.86 per cent $\mathrm{NaCl}+0.5$ per cent dextrose +0.2

POST-TRANSFUSION SURVIVAL OF HUMAN ERYTHROCYTES

STORED AS RESUSPENSIONS IN ELECTROLYTE SOLUTIONS AT $4^{\circ} \mathrm{C}$.

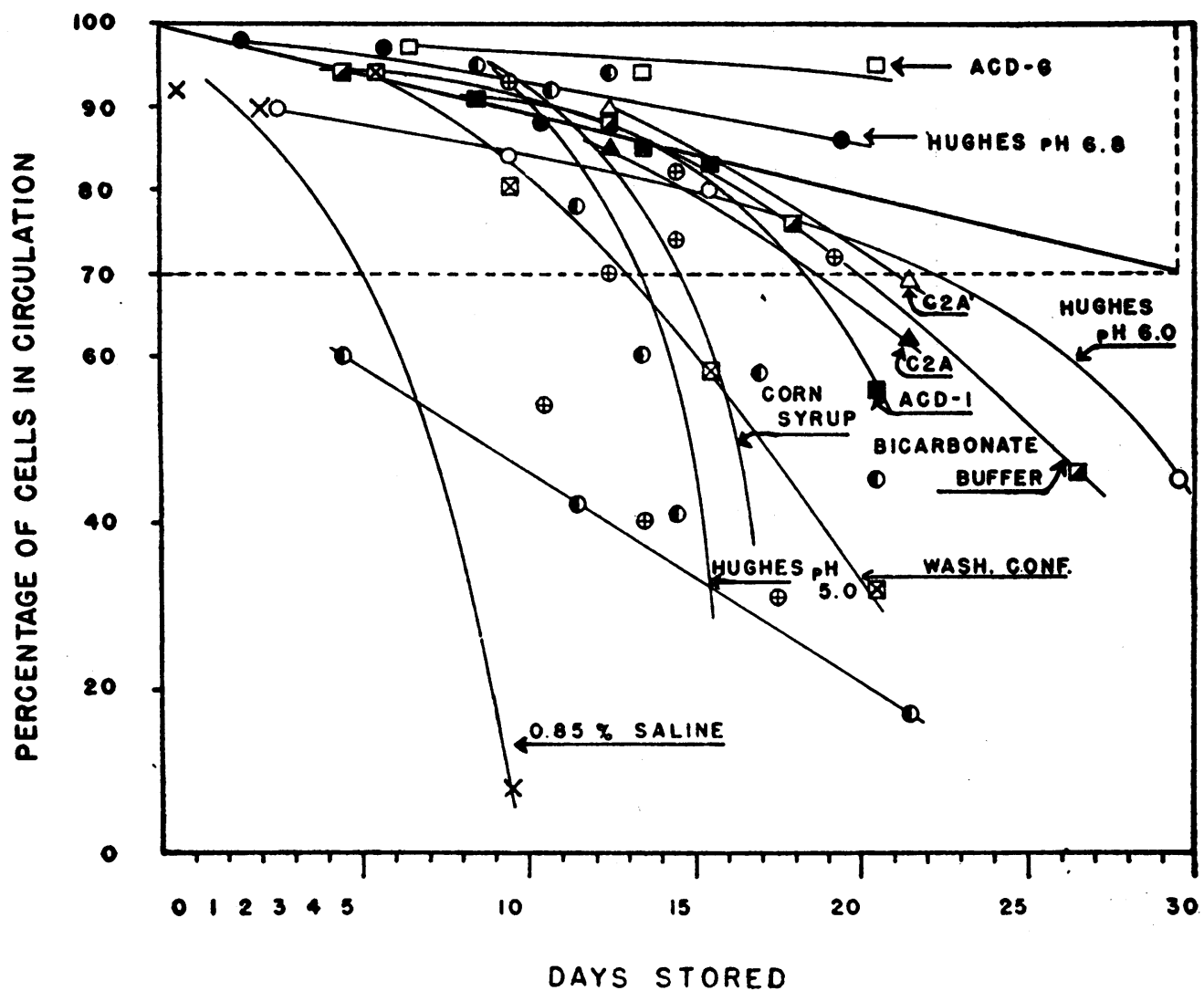

Fig. 2. Post-Transfusion Survival of Human Erythrocytes Stored as Resuspensions in Electrolyte Solutions at $4^{\circ} \mathrm{C}$.

Symbols refer to the following solutions:

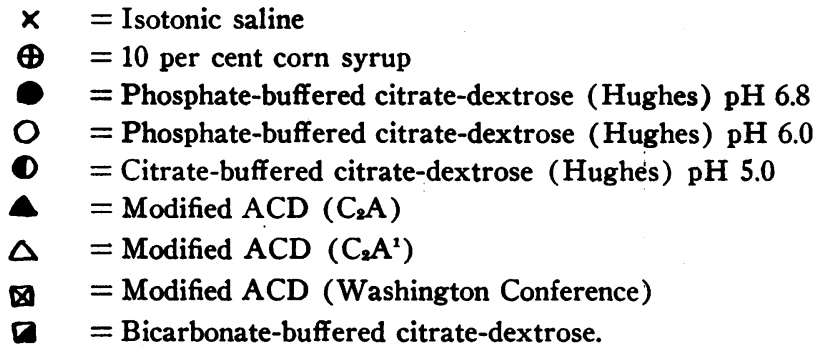

The symbols $\square$ and $\square$ refer to packed cells in ACD-1 and ACD-G stored without resuspension. 
TABLE IV

Post-transfusion survival of human erythrocytes drawn as whole blood in acid-citrate-dextrose and stored at $4^{\circ} \mathrm{C}$. with and without resuspension after removal of plasma

\begin{tabular}{|c|c|c|c|c|c|c|c|c|c|c|}
\hline \multirow{3}{*}{$\begin{array}{l}\text { Preservative } \\
\text { solution }\end{array}$} & \multirow{2}{*}{$\begin{array}{c}\text { Trans- } \\
\text { fusion } \\
\text { no. }\end{array}$} & \multirow{2}{*}{$\begin{array}{l}\text { Days } \\
\text { stored }\end{array}$} & \multirow{2}{*}{$\begin{array}{l}\text { Recip. } \\
\text { blood } \\
\text { group }\end{array}$} & \multirow{2}{*}{ Diluent added } & \multirow{2}{*}{$\begin{array}{l}\text { Quan- } \\
\text { tity } \\
\text { added }\end{array}$} & \multicolumn{2}{|c|}{$\begin{array}{c}\text { Transfused } \\
\text { volume }\end{array}$} & \multirow{2}{*}{ Clots } & \multirow{2}{*}{$\begin{array}{l}\text { Reac- } \\
\text { tions }\end{array}$} & \multirow{2}{*}{ Survival } \\
\hline & & & & & & Total & Cells & & & \\
\hline & & & & & $m l$. & $m l$. & $m l$. & & & per cent \\
\hline
\end{tabular}

Diluent added at time of transfusion

\begin{tabular}{|c|c|c|c|c|c|c|c|c|c|c|}
\hline $\begin{array}{l}\text { ACD-1 } \\
(22)\end{array}$ & $\begin{array}{l}115 \\
116 \\
117 \\
118 \\
119\end{array}$ & $\begin{array}{r}15 \\
16 \\
9 \\
14 \\
21\end{array}$ & $\begin{array}{l}\mathbf{A} \\
\mathbf{A} \\
\mathbf{A} \\
\mathbf{0} \\
\mathbf{A}\end{array}$ & $\begin{array}{l}0.85 \text { per cent } \mathrm{NaCl} \\
0.85 \text { per cent } \mathrm{NaCl} \\
0.85 \text { per cent } \mathrm{NaCl} \\
0.85 \text { per cent } \mathrm{NaCl} \\
0.85 \text { per cent } \mathrm{NaCl}\end{array}$ & $\begin{array}{r}0 \\
125 \\
125 \\
125 \\
125\end{array}$ & $\begin{array}{l}158 \\
425 \\
345 \\
363 \\
278\end{array}$ & $\begin{array}{l}138 \\
226 \\
227 \\
232 \\
161\end{array}$ & $\begin{array}{l}+ \\
0 \\
+ \\
0 \\
+\end{array}$ & $\begin{array}{l}\mathbf{0} \\
\mathbf{0} \\
\mathbf{0} \\
\mathbf{0} \\
\mathbf{0}\end{array}$ & $\begin{array}{l}76 \\
83 \\
91 \\
85 \\
56\end{array}$ \\
\hline \multirow{5}{*}{$\underset{(23)}{A C D-G}$} & $\begin{array}{l}160 \\
162 \\
164 \\
166 \\
168 \\
170 \\
171 \\
172 \\
173\end{array}$ & $\begin{array}{l}7 \\
14 \\
21 \\
12 \\
19 \\
27 \\
13 \\
21 \\
14\end{array}$ & $\begin{array}{l}\mathbf{B} \\
\mathbf{0} \\
\mathbf{0} \\
\mathbf{0} \\
\mathbf{0} \\
\mathbf{B} \\
\mathbf{0} \\
\mathbf{0} \\
\mathbf{B}\end{array}$ & $\begin{array}{l}0.85 \text { per cent } \mathrm{NaCl} \\
0.85 \text { per cent } \mathrm{NaCl} \\
0.85 \text { per cent } \mathrm{NaCl} \\
0.85 \text { per cent } \mathrm{NaCl} \\
0.85 \text { per cent } \mathrm{NaCl} \\
0.85 \text { per cent } \mathrm{NaCl} \\
1 \text { per cent } \mathrm{NaCl} \\
1 \text { per cent } \mathrm{NaCl} \\
1 \text { per cent } \mathrm{NaCl}+0.5\end{array}$ & $\begin{array}{r}0 \\
0 \\
0 \\
125 \\
125 \\
125 \\
100 \\
100 \\
100\end{array}$ & $\begin{array}{l}141 \\
138 \\
102 \\
353 \\
368 \\
335 \\
255 \\
229 \\
234\end{array}$ & $\begin{array}{r}122 \\
119 \\
87 \\
236 \\
242 \\
197 \\
128 \\
108 \\
112\end{array}$ & $\begin{array}{l}0 \\
++ \\
++ \\
0 \\
++ \\
++ \\
+ \\
0 \\
0\end{array}$ & $\begin{array}{l}\mathbf{0} \\
0 \\
0 \\
0 \\
0 \\
0 \\
0 \\
0 \\
0\end{array}$ & $\begin{array}{r}97 \\
94 \\
81 \\
98 \\
67 \\
46 \\
100 \\
86 \\
100\end{array}$ \\
\hline & 174 & 22 & A & 1 per cent $\mathrm{NaCl}+0.5$ & 100 & 215 & 103 & + & 0 & 73 \\
\hline & 176 & 14 & B & 0.86 per cent $\mathrm{NaCl}+$ & 100 & 222 & 112 & + & 0 & 95 \\
\hline & 175 & 20 & 0 & 0.86 per cent $\mathrm{NaCl}+$ & 100 & 220 & 124 & $+t+$ & 0 & 87 \\
\hline & $\begin{array}{l}178 \\
177\end{array}$ & $\begin{array}{l}15 \\
21\end{array}$ & $\begin{array}{l}\mathbf{0} \\
\mathbf{A}\end{array}$ & $\begin{array}{l}10 \text { per cent corn syrup } \\
10 \text { per cent corn syrup }\end{array}$ & $\begin{array}{l}100 \\
100\end{array}$ & $\begin{array}{l}204 \\
220\end{array}$ & $\begin{array}{l}128 \\
135\end{array}$ & + & $\begin{array}{l}\mathbf{0} \\
\mathbf{0}\end{array}$ & $\begin{array}{l}64 \\
81\end{array}$ \\
\hline
\end{tabular}

Stored with diluent added

\begin{tabular}{|c|c|c|c|c|c|c|c|c|c|c|}
\hline \multirow{8}{*}{$\underset{(23)}{A C D-G}$} & 180 & 12 & A & 1.1 per cent $\mathrm{NaCl}+$ & 100 & 215 & 104 & ++ & 0 & 92 \\
\hline & 181 & 19 & 0 & 1.1 per cent $\mathrm{NaCl}+$ & 100 & 245 & 118 & ++ & $\mathbf{0}$ & 78 \\
\hline & $182 \cdot$ & 13 & 0 & 0.85 per cent $\mathrm{NaCl}+$ & 100 & 216 & 115 & ++ & 0 & 83 \\
\hline & 183 & 20 & A & 0.85 per cent $\mathrm{NaCl}+$ & 100 & 213 & 109 & + & $\mathbf{0}$ & 69 \\
\hline & 184 & 13 & A & 0.6 per cent $\mathrm{NaCl}+$ & 100 & 223 & 125 & + & 0 & 71 \\
\hline & 185 & 20 & 0 & 0.6 per cent $\mathrm{NaCl}+$ & 100 & 236 & 130 & + & 0 & 64 \\
\hline & 186 & 14 & $\mathbf{A}$ & $\begin{array}{l}0.86 \text { per cent } \mathrm{NaCl}+ \\
0.5 \text { per cent dext. }+\end{array}$ & 100 & 269 & 149 & $+t+$ & $\mathbf{0}$ & 62 \\
\hline & 187 & 21 & $\mathbf{0}$ & $\begin{array}{l}0.2 \text { per cent } \mathrm{NaCl}+ \\
0.5 \text { per cent dext. }+ \\
0.2 \text { per cent citric acid }\end{array}$ & 100 & 211 & 112 & + & $\mathbf{0}$ & 48 \\
\hline
\end{tabular}

per cent citric acid. Two hundred fifty $\mathrm{ml}$. of blood were taken into each of 2 bottles from the same donor. One hundred $\mathrm{ml}$. of diluent were added immediately after removal of plasma. The resuspensions were transfused after 14 and 21 days of storage.

The results of experiments on packed cells are summarized in Table IV and shown in Figures 2 and 4.
Experiments on electrolyte solutions with added human serum protein fractions 8

The albumin used, Fraction V, was the commercial product supplied to the U. S. Navy. The globulins, Frac-

8 The human serum proteins were obtained through the courtesy of Dr. E. J. Cohn. 


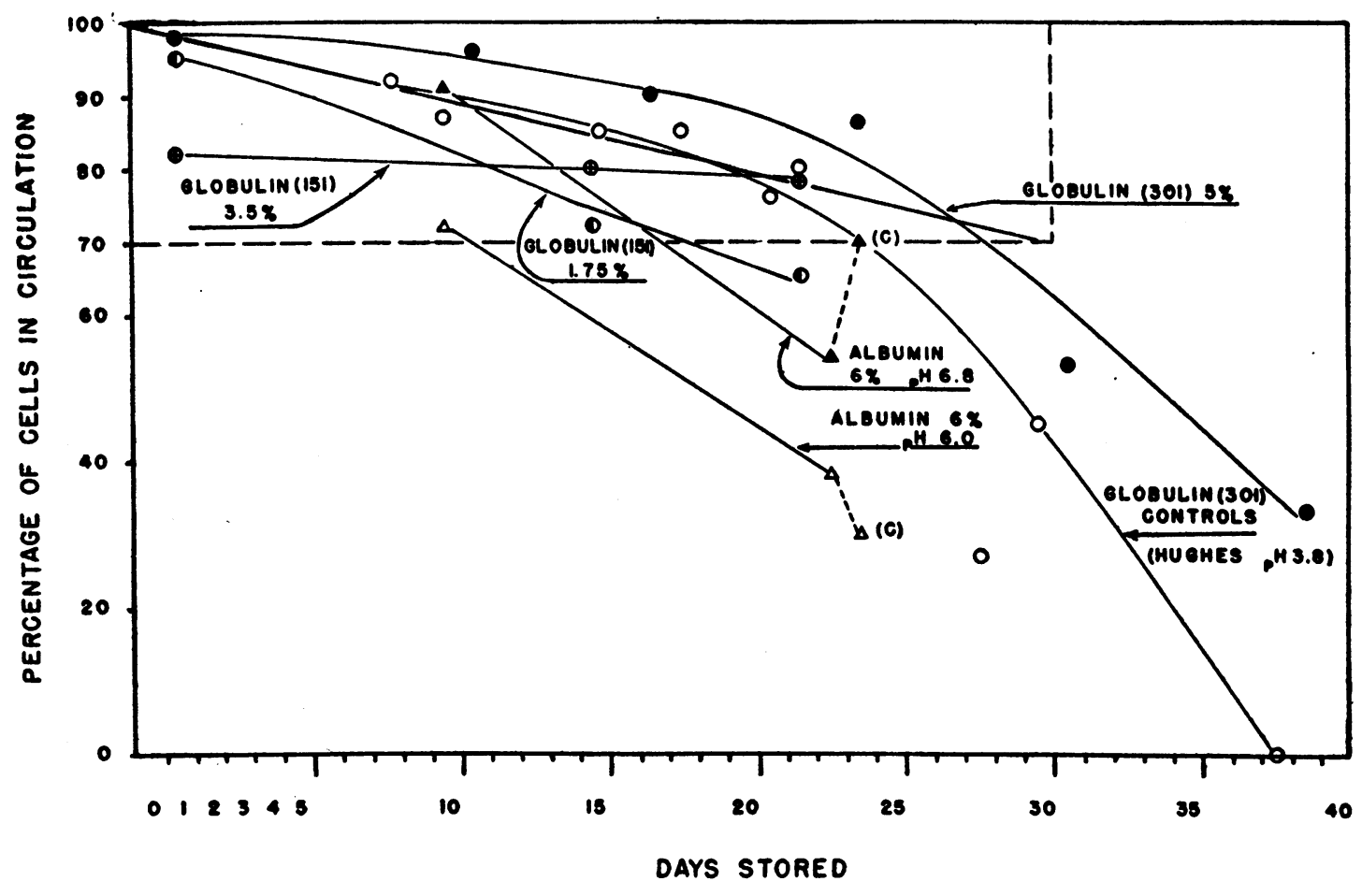

Fig. 3. Post-Transfusion Survival of Human Erythrocytes Stored in Resuspension in ProteinThe symbols refer to the following solutions: Fortified Solutions at $4^{\circ} \mathrm{C}$.
$\Delta=$ Human serum albumin added to phosphate-buffered citrate-dextrose at $\mathrm{pH} 6.8$.
$\Delta=$ Human serum albumin added to phosphate-buffered citrate-dextrose at $\mathrm{pH} 6.0$.
$\underset{0}{\oplus}$ = Human serum globulin (Lot 151) added to citrate-buffered citrate-dextrose, $\mathrm{pH}$ 7.0.
- Human serum globulin (Lot 301 ) added to citrate-buffered citrate-dextrose, $\mathrm{pH} 3.8$.
O The globulin-free controls for globulin 301.

tion IV-3, $4,{ }^{\circ}$ were prepared in the pilot plant of the Department of Physical Chemistry, Harvard Medical School. Red cells resuspended in a solution, of the same composition as that to which the proteins were added, were used for control transfusions.

${ }^{\circ}$ Safety tests on Fraction IV-3, 4 were carried out by Dr. O. Krayer, in animals, and by Dr. C. A. Janeway, in humans.
(24 AND 25) HUMAN SERUM ALbUMin (FRACTION V) IN PHOSPHATE-BUFFERED CITRATE-DEXTROSE SOLUTIONS AT PH 6.8 AND 6.0. OPEN BURETTE METHOD

Experiments Nos. 36, 37 (6.8), Experiments Nos. 39, 40 (6.0), and Experiments Nos. 38 and 41 (controls). With venesection the donor was bled into four $250-\mathrm{ml}$. storage bottles, designated as bottles (a), (b), (c), and (d). Bottles (a) and (b) each contained $20 \mathrm{ml}$. of 4 per cent sodium citrate solution, and each received $200 \mathrm{ml}$. 
of donor blood. Bottles (c) and (d) each contained 10 ml. of 4 per cent sodium citrate solution, and each of these received $100 \mathrm{ml}$. of the blood. These were stored at $4^{\circ} \mathrm{C}$. over night, and then all 4 bottles were centrifuged, and the plasma was removed. To each bottle of packed cells was added a volume of resuspension solution approximately equal to the volume of plasma withdrawn. Bottle (a) received albumin solution buffered to a $\mathrm{pH}$ of 6.8 . Bottle

\section{POST TRANSFUSION SURVIVAL \\ OF CENTRIFUGED ACD CELLS}
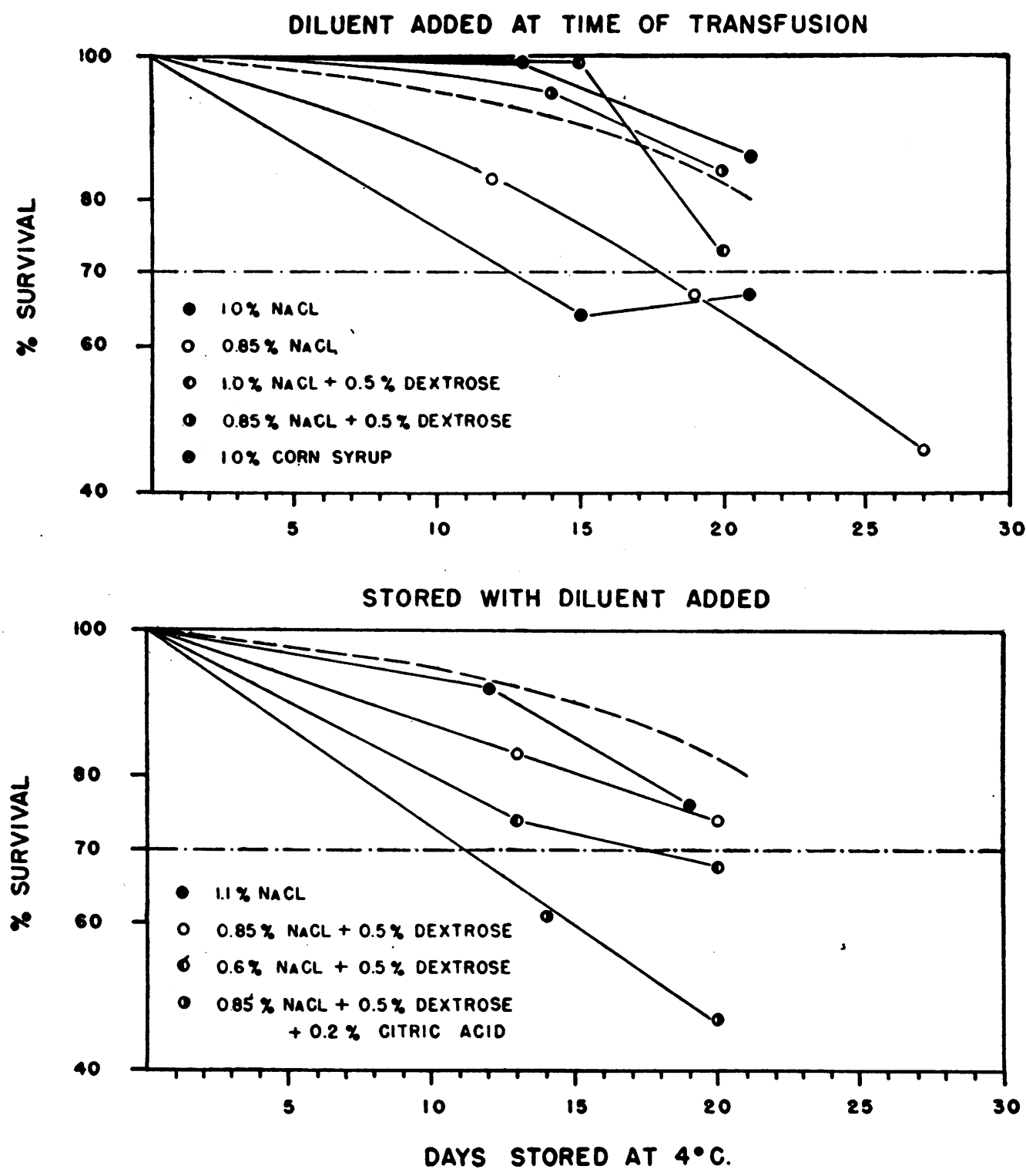

Fig. 4. Post-Transfusion Survival of Centrifuged ACD Cells

The addition of a slightly hypertonic saline solution just prior to transfusion does not decrease the viability of packed red cells drawn as whole blood in ACD. Storage in these same diluents increases the rate of deterioration. 
(b) received albumin solution buffered to a $\mathrm{pH}$ of 6.0 . Bottle (c) received albumin-free solution buffered to a $\mathrm{pH}$ of 6.8 , and bottle (d) received albumin-free solution bufferred to a pH of 6.0. Bottles (a) and (b) were each subdivided into 2 equal aliquots. The entire procedure was carried out at room temperature. After 10 days of storage, an aliquot of cells resuspended in albumin $\mathrm{pH} 6.8$ and one of cells resuspended in albumin $\mathrm{pH} 6.0$ were transfused. After 23 storage days the 2 remaining albumin-containing aliquots were transfused. The control aliquots, that is, cell resuspended in a solution buffered to 6.8 and 6.0 (no albumin), were both transfused after 24 days of storage.

(26) $\alpha$ AND $\beta$ GLOBULINS (FRACTION IV- 3,4 , LOT 151) IN ACIDIFIED-CITRATE-DEXTROSE (HUGHES PH 3.8)

Experiments Nos. 82 through 87 . The globulin was dissolved in the electrolyte solution, in 2 portions, the final concentration of protein being 1.75 and 3.50 grams per $100 \mathrm{ml}$. Five hundred $\mathrm{ml}$. of blood from each of 2 donors were drawn into 4 per cent sodium citrate at room temperature. The blood was centrifuged within 24 hours, and the plasma was withdrawn. To 1 bottle was added the 1.75 per cent globulin solution and to the other, the 3.50 per cent globulin solution. The globulin solution was cold. After thorough mixing, 3 equal aliquots of each were transferred to storage bottles. Each aliquot was transfused after storage for 1,15 , and 22 days respectively.
(27) $\alpha$ AND $\beta$ GLOBULINS (FRACTION IV-3, 4; LOT 301)

Experiments Nos. 88, 90, 92, 94, 106, 108. (Controls $89,91,93,105,107,109,110$ through 112 are described above.) Three grams of the globulin were dissolved in $100 \mathrm{ml}$. of the electrolyte solution. Two series of experiments were carried out, in one of which each test and control transfusion was a full bleeding, in the other of which each was a half-size bleeding. Resuspension was completed within 18 hours of drawing the blood. All solutions were cold and the packed cells were refrigerated.

Test transfusions were given $1,11,17,24,32$, and 39 days, and control transfusions, $8,10,15,18,21,22,28,31$, and 38 days after bleeding.

The results of these experiments are summarized in Table V and Figure 3.

\section{RESULTS}

\section{Whole blood}

The poorest survival of whole blood was obtained with 4 per cent sodium citrate (No. 1). After 4 days of storage, 90 per cent of the cells were viable, but thereafter deterioration was precipitous.

All of the other solutions contained dextrose. The simplest of these, citrate and dextrose, was

TABLE $V$

Post-transfusion survival of human erythrocytes drawn as whole blood in 4 per cent sodium citrate and stored at $4^{\circ} \mathrm{C}$. after resuspension in human serum protein-fortified electrolyte solutions

\begin{tabular}{|c|c|c|c|c|c|c|c|c|c|}
\hline \multirow{2}{*}{ Solution } & \multirow{2}{*}{$\begin{array}{l}\text { Trang- } \\
\text { fusion } \\
\text { no. }\end{array}$} & \multirow{2}{*}{$\begin{array}{c}\text { Days } \\
\text { stored }\end{array}$} & \multirow{2}{*}{$\begin{array}{l}\text { Recip. } \\
\text { blood } \\
\text { group }\end{array}$} & \multicolumn{2}{|c|}{$\begin{array}{c}\text { Transfused } \\
\text { volume }\end{array}$} & \multirow{2}{*}{$\begin{array}{l}\text { Age of } \\
\text { tagged } \\
\text { cells* }\end{array}$} & \multirow{2}{*}{ Clots } & \multirow{2}{*}{$\begin{array}{c}\text { Reactions } \\
\text { (febrile) }\end{array}$} & \multirow{2}{*}{ Survival } \\
\hline & & & & Total & Cells & & & & \\
\hline $\begin{array}{l}5 \text { per cent albumin }+ \text { Hughes } \\
\text { pH } 6.8 \text { (24) }\end{array}$ & $\begin{array}{l}36 \\
37\end{array}$ & $\begin{array}{l}10 \\
23\end{array}$ & $\begin{array}{l}\mathbf{0} \\
\mathbf{0}\end{array}$ & $\begin{array}{r}m l . \\
67 \\
77\end{array}$ & $\begin{array}{r}m l . \\
33 \\
39\end{array}$ & $\begin{array}{l}27 \\
27\end{array}$ & $\begin{array}{l}++ \\
+++\end{array}$ & + & $\begin{array}{l}\text { per cent } \\
91 \\
54\end{array}$ \\
\hline Hughes pH 6.8 & 38 & 24 & 0 & 75 & 39 & 27 & $+t$ & 0 & 70 \\
\hline $\begin{array}{l}5 \text { per cent albumin }+ \text { Hughes } \\
\text { pH } 6.0(25)\end{array}$ & $\begin{array}{l}39 \\
40\end{array}$ & $\begin{array}{l}10 \\
23\end{array}$ & $\begin{array}{l}0 \\
0\end{array}$ & $\begin{array}{l}74 \\
71\end{array}$ & $\begin{array}{l}36 \\
35\end{array}$ & $\begin{array}{l}27 \\
27\end{array}$ & $\begin{array}{l}++ \\
++\end{array}$ & $\begin{array}{l}0 \\
0\end{array}$ & $\begin{array}{l}72 \\
38\end{array}$ \\
\hline Hughes pH 6.0 & 41 & 24 & 0 & 82 & 38 & 27 & +++ & + & 30 \\
\hline $\begin{array}{l}\text { Fraction IV-3, } 4 \text { (151) } \\
1.75 \text { per cent in Hughes } \\
(26)\end{array}$ & $\begin{array}{l}82 \\
84 \\
86\end{array}$ & $\begin{array}{r}1 \\
15 \\
22\end{array}$ & $\begin{array}{l}\mathbf{0} \\
\mathbf{0} \\
\mathrm{A}\end{array}$ & $\begin{array}{l}167 \\
143 \\
142 \\
\end{array}$ & $\begin{array}{l}79 \\
68 \\
68\end{array}$ & $\begin{array}{l}132 \\
132 \\
132\end{array}$ & $\begin{array}{l}+ \\
+\end{array}$ & $\begin{array}{l}\mathbf{0} \\
0 \\
0\end{array}$ & $\begin{array}{l}82 \\
80 \\
78\end{array}$ \\
\hline $\begin{array}{l}\text { Fraction IV-3, } 4 \text { (151) } \\
\text { 3.5 per cent in Hughes } \\
\text { (26) }\end{array}$ & $\begin{array}{l}83 \\
85 \\
87\end{array}$ & $\begin{array}{r}1 \\
15 \\
22\end{array}$ & $\begin{array}{l}\mathbf{0} \\
\mathbf{0} \\
\mathbf{A}\end{array}$ & $\begin{array}{l}166 \\
146 \\
141\end{array}$ & $\begin{array}{l}77 \\
68 \\
67\end{array}$ & $\begin{array}{l}141 \\
141 \\
141\end{array}$ & $\begin{array}{c}+ \\
+ \\
+\end{array}$ & $\begin{array}{l}\mathbf{0} \\
0 \\
0\end{array}$ & $\begin{array}{l}95 \\
72 \\
65\end{array}$ \\
\hline $\begin{array}{l}\text { Fraction IV-3, } 4 \text { (301) } \\
\text { in Hughes (27) }\end{array}$ & $\begin{array}{r}88 \\
90 \\
92 \\
94 \\
106 \\
108\end{array}$ & $\begin{array}{l}1 \\
11 \\
17 \\
24 \\
32 \\
39\end{array}$ & $\begin{array}{l}\mathbf{A} \\
\mathbf{A} \\
\mathbf{A} \\
\mathbf{A} \\
\mathbf{0} \\
\mathbf{0}\end{array}$ & $\begin{array}{l}505 \\
488 \\
525 \\
275 \\
198 \\
117\end{array}$ & $\begin{array}{r}212 \\
195 \\
215 \\
113 \\
90 \\
55\end{array}$ & $\begin{array}{l}181 \\
104 \\
104 \\
181 \\
104 \\
104\end{array}$ & $\begin{array}{c}0 \\
++ \\
++ \\
+ \\
+ \\
+\end{array}$ & $\begin{array}{l}0 \\
0 \\
0 \\
0 \\
0 \\
0\end{array}$ & $\begin{array}{l}98 \\
96 \\
90 \\
85 \\
53 \\
33\end{array}$ \\
\hline
\end{tabular}

* Days between last injection of radioactive iron and day of bleeding. 
De Gowin's solution (No. 3). Although there seemed to be some immediate cell damage, subsequent deterioration proceeded at a rate of less than 1 per cent a day up to about 20 days of storage, at which period 80 per cent of the cells proved to be viable. Thereafter, the survival curve broke sharply.

The 2 unmodified E.T.O. A and B solutions (Nos. 8 and 9) were fortified with dextrose, solution $\mathrm{B}$ also containing sodium chloride. Survival in both solutions was considerably better than in plain citrate, the 70 per cent levels being reached in about 11 and 15 days respectively.

Two solutions were buffered with phosphates, at 7.4 (McGill II) (No. 2), and at 7.1 (Parpart's) (No. 5). Survival in McGill II solution was about 90 per cent at 10 days of storage, but thereafter the rate of deterioration increased rapidly, the 70 per cent level coming on the sixteenth day. Very good preservation was obtained with Parpart's solution, even though some initial hemolysis may have been caused by taking the blood over dry citrate. During 26 days of storage, only about 10 per cent of the cells became nonviable.

The $\mathrm{pH}$ of Alsever's solution (No. 4) was adjusted to 6.8 with citric acid. Deterioration was fairly constant up to about 15 days of storage, when about 80 per cent of the cells were viable, the 70 per cent level being reached on the twentieth day.

Four solutions were adjusted to a $\mathrm{pH}$ of 5.0 : E.T.O. Modifications A and B (Nos. 10 and 11) by hydrochloric acid, and ACD-1 (No. 6) and ACD-G (No. 7) by citric acid. Bloods in both of the modified E.T.O. solutions showed a constant rate of deterioration approximating 1 per cent per day, the 80 per cent level being reached in 20 and 16 days, respectively. This series was not followed down to the 70 per cent survival level. Both the ACD solutions gave very satisfactory preservation. Blood in ACD-1 deteriorated at less than 1 per cent per day for 25 days, and in ACD-G for 22 days, at which survival in both solutions was at least 80 per cent.

Deterioration of red cells resuspended in normal saline (No. 12) was rapid, the 90 per cent level being reached in 3 days, and practically no cells being viable after 10 days of storage.

Survival in the first series of cells in corn syrup (No. 13) was poor, the 70 per cent level being reached in about 4 days, but was considerably better in the second series. A wide scatter in survival was found in this series, in which the subjects were hospitalized patients, but it is evident that preservation was satisfactory for at least 10 days.

Both the phosphate-buffered solutions (Nos. 14 and 15) gave good preservation.

Surivival of cells in the $\mathrm{pH} 6.8$ solution was better than 80 per cent up to the longest storage period studied, 20 days; and the survival of cells in the $\mathrm{pH} 6.0$ solution was 70 per cent at 22 days.

The citrate-buffered solution adjusted to $\mathrm{pH} 3.8$ with $\mathrm{HCl}$ ( $\mathrm{No} .27$, controls ${ }^{10}$ ) was better than that adjusted to $\mathrm{pH} 5.1$ (No. 16), the 70 per cent survival levels being reached in 20 and 14 days respectively.

Two other citrate-buffered solutions, $\mathrm{C}_{2} \mathrm{~A}$ (No. 18) and $C_{2} A^{1}$ (No. 19), gave fairly good preservation, the 70 per cent levels being reached at 21 and 18 days respectively.

The low volume citrate-buffered solution (No. 20) gave poor preservation, the survival level having fallen to about 10 days, and to less than 60 per cent after 16 days of storage.

Survival of cells in the bicarbonate-buffered solution (No. 21) was 70 per cent after 20 days but only about 40 per cent after 26 days of storage.

\section{Packed red cells}

Red cells drawn into ACD-G, stored as centrifuged cells with the plasma removed, and transfused up to 21 days of storage without the addition of any diluent, survived as well as whole blood in the same solution. The addition of 0.85 per cent $\mathrm{NaCl} ; 1.1$ per cent, 0.85 per cent and 0.6 per cent $\mathrm{NaCl}$ plus 0.5 per cent of dextrose ; and of 0.85 per cent $\mathrm{NaCl}$ plus 0.5 per cent dextrose and 0.2 per cent citric acid decreased the viability of the cells as compared to whole blood, the 70 per cent level being reached at from 12 to 18 days.

The addition just prior to transfusion of 1.0 per cent $\mathrm{NaCl}$; of 1.0 per cent $\mathrm{NaCl}$ plus 0.5 per cent dextrose; and of 0.85 per cent $\mathrm{NaCl}$ plus 0.5 per cent dextrose did not increase the viability of the cells as compared with whole blood. Results with the addition of 10 per cent corn syrup were equivocal.

\footnotetext{
10 Illustrated in Figure 3.
} 
Solutions with added human serum protein fractions.

Human serum albumin (Nos. 24 and 25) did not increase the preservative quality of the electrolyte solution in which it was added (Nos. 14 and 15). Fraction IV-3, 4, composed of $\alpha$ and $\beta$ globulins and albumin, apparently had a beneficial effect. With one lot of globulin (No. 26) survival of better than 70 per cent was obtained for 15 days. With the other lot (No. 27) survival of cells in the globulin-containing solution was better than 80 per cent for 24 days of storage, but survival of the cells in the control solution had fallen to 71 per cent over a similar storage period.

\section{DISCUSSION}

Most of the experimental subjects were normal ambulatory males. In the series of cells resuspended in corn syrup (Experiments Nos. 140 through 147), and Hughes $\mathrm{pH} 5.1$ solution (Experiments Nos. 132 through 139), hospitalized patients were used. It will be noted in Figure 2 that the scatter in percentage of survival throughout the period of observation ( 9 to 20 days) was much greater in both series than that seen in the normal recipients. Most of these patients were anemic, some were mildly febrile, some had gastrointestinal lesions, others were postoperative, and one under daily X-ray therapy for carcinomatosis. Similar observations on survival of radioactively tagged stored red cells are reported by Denstedt (47) in mental cases and by Strumia (48) in hospital ward patients. Accordingly, the survival in normals may be regarded as the best experimental basis for the comparative evaluation of viability of blood stored in various solutions.

The size of transfusions given varied from full bleedings ( 150 to $250 \mathrm{ml}$. of cells) to small aliquots (25 to $100 \mathrm{ml}$. of cells). Thus, the amounts transfused represented variable percentages of the recipient's pre-transfusion red cell volume. Since the recipients' red cell volumes ranged from about 1,800 to $2,500 \mathrm{ml}$., the transfusions ranged from 1 to 15 per cent of total red cell volume. The time in which the transfusion was given, and hence the average rate of flow, also varied.

The absolute quantities of non-viable cells varied, in these experiments, with the size of the transfusion and the percentage of survival. While these factors might well influence the rate at which nonviable cells or hemoglobin were removed from circulation, it is hardly to be expected that many nonviable cells, even in a badly deteriorated blood, would remain in active circulation for any considerable period of time. Thus the accuracy with which the proportion of non-viable to viable transfused cells was measured was not affected by the size of the transfusion.

In the paper in which the radioactive iron method of measuring post-transfusion survival of transfused red cells (40) was described, the percentage of survival, that is, the percentage of transfused cells found viable, was based upon the lowest radioactivity value of the recipient's red cells found during the observation period. This low point occurred within the first 24 hours after transfusion in the majority of cases, and seldom beyond the first 48 hours after transfusion.

Recipient radioactivity levels after 48 hours constitute the sum of radioactivity of retained donor cells and of new cells containing re-utilized radio-iron. Thus the method does not measure the continued longest period of survival of viable donor cells in the recipient's blood stream. However, the chief danger from the transfusion of stored blood lies in the extent of breakdown of donor cells, and hence the immediate survival of the transfused cells becomes a factor of paramount importance in evaluating preservative solutions.

The limit of error of the technic was defined as \pm 5 per cent. In those cases in which the loss of cells was considerable, it is possible that some reutilization of liberated radio-iron had already occurred at the time that the lowest recipient radioactivity value was obtained. If such were the case, the extreme loss of transfused cells might not have been detected, and the computed survival may have been falsely high. In all probability this potential error is not significant in the results obtained on bloods showing better than 60 per cent survival.

It should be clearly understood that only radioactively tagged erythrocytes are detected by the analytic procedures employed. The exact percentage of tagged cells of given ages in the blood of any donor cannot be calculated from the data available, since the quantity of the radio-iron in the individual corpuscles was not measured, nor is it certain that radio-iron is evenly distributed in all developing cells. The time elapsed between the 
first exposure of a donor to radio-iron and the drawing of blood from that donor is known and is listed for each transfusion in Tables II through V. Thus it is possible to consider donors as having predominantly young, middle-aged, or old tagged cells. Those donors in whom the time interval between administration of radio-iron and drawing of blood exceeded the normal life span of the red cell (about 100 days) may be considered as having, to an unknown extent, a mixed-age cell population. The longer the time interval, the more closely would the age distribution of the tagged cells approach the age distribution of all the circulating cells.

It was also stated (40) that the age of the radioactively tagged cells at the time the blood was drawn was a factor in the rate of deterioration of the cells during storage; that very young cells survived about 10 per cent better during storage than did cells of advanced age. In those experiments in which only young tagged cells were given, the survival percentages might therefore be expected to be somewhat better than if tagged cells of ages more nearly representative of the whole red cell population had ben used.

Thus, the survival of tagged cells from any donor could be expected to be best when all cells are young and to become progressively poorer as they approach the end of their life span. After that time, survival would be improved due to the presence of new cells tagged with re-utilized radio-iron. This phenomenon would continue until all ages of cells were represented by tagged cells, and the measured survival of the radioactive cells would be truly representative of the survival of the blood as a whole.

The maximum differential in survival of young and old cells is 10 per cent, and the degree of this error will tend to diminish the more closely the age distribution of the tagged cells approaches that of a truly mixed-age red cell population. This factor, slight as it is, has been taken into consideration in the final evaluation of the preservative solutions studied.

In general, evidence, by the radioactive method, of good preservation is slightly more significant when the transfusion contained predominantly old or mixed-age tagged cells, than when the tagged cells were young. Conversely, evidence of poor preservation is more significant when the transfu- sion contained young tagged cells, than when the tagged cells were of mixed or advanced age.

Studies by Shemin and Rittenberg, employing $\mathrm{N}^{15}$, have demonstrated that the normal life span of human erythrocytes is from 100 to 120 days (33). It can therefore be assumed that red cells normally die off at the rate of about one per cent a day in the body. It follows that if cells deteriorate at a similar rate during storage, as determined by posttransfusion survival, preservation in vitro has been as good as if they had remained in circulation in the body.

Survival at a rate equivalent to the post-transfusion loss of not more than 1 per cent of the transfused cells per day of storage would therefore seem a reasonable standard for "satisfactory" preservation. The slope of this rate of survival is plotted in broken lines in Figures 1, 2, 3.

This does not imply that blood showing higher rates of deterioration cannot be safely transfused. As will be shown in a subsequent communication (49), the normal reticulo-endothelial and erythropoietic system is capable of disposing of red cell breakdown products up to 30 per cent of a $500 \mathrm{ml}$. transfusion without marked hemoglobinemia or hemoglobinuria. One important factor is, therefore, the storage period at which not less than 70 per cent of transfused cells survive. With what we have defined above as "satisfactory" preservation, survival would decline to this level in 30 days. This "zone of safe transfusion" is indicated by the dotted rectangle in Figures 1 through 3.

Inspection of the time-survival curves in these figures reveals that the initial rate of deterioration remains fairly constant throughout the observation period, but in others becomes accelerated at some point during continued storage.

This constant rate of deterioration is illustrated in Figure 1 by the time-survival curves of Parpart's solution, ACD-1 and ACD-G, and E.T.O. Modification A. The acceleration in rate of deterioration is illustrated by the time-survival curves in Figure 1 of citrated blood, McGill II, De Gowin's and Alsever's solution, and in Figure 3, by the curves of cells resuspended in the globulin-fortified (301) acid-citrate dextrose solution, and the $\mathrm{pH}$ 3.8 controls. The preservative showing a low and constant rate of deterioration over substantial periods would appear to be superior to one in which an abrupt change was observed. 
Both of those characteristics must be considered in determining the longest permissible dating period of blood stored in any preservative.

The storage period at which the rate of deterioration began to exceed 1 per cent per day, and at which the smoothed time survival curves intersect the 70 per cent survival abscissa, is shown in Table VI for each solution studied. In those series in which survival did not fall below 70 per cent, the percentage of survival obtained on the longest observed storage period is listed. Also given in the table are "dating periods"-the longest permissible safe periods of refrigerated storage.

Any dating period is at best an approximation. Blood from individual donors presents one variable, and the state of health of recipients many more variables. The manner in which blood is drawn, and its subsequent handling also may affect behavior during storage. The determination of upper limits of storage should be based on conservative rather than optimistic considerations.

It is recognized that the ability of the human body to dispose of red cell breakdown products is extremely variable and may be far greater than hitherto believed. In the opinion of the authors, safe practice would appear to be to give the patient, not the preservative solution, the benefit of the doubt.

These values have been arrived at by considering the characteristics of the time-survival curves : the storage period at which the rate of deterioration began to exceed 1 per cent per day and the survival had dropped off to 70 per cent (where observed). The age of the tagged cells was also considered according to the general statement made above.

There are obviously wide differences in the preservative qualities of the solutions studied. They may be grouped according to dating period somewhat as shown in Table VII.

In light of the data presented, it can be empirically stated that maximal preservation of cells stored as whole blood is obtained with a solution in which

(a) the ratio of whole blood to diluent is not less than 4 to 1 ;

(b) the concentration of citrate in diluted plasma is between 0.4 and 0.6 grams per $100 \mathrm{ml}$. (about 1.0 gram per $100 \mathrm{ml}$. of packed cells);
TABLE VI

Storage periods at which rate of deterioration begins to exceed 1 per cent per day, at which the 70 per cent survival level is reached, and approximate "dating periods"

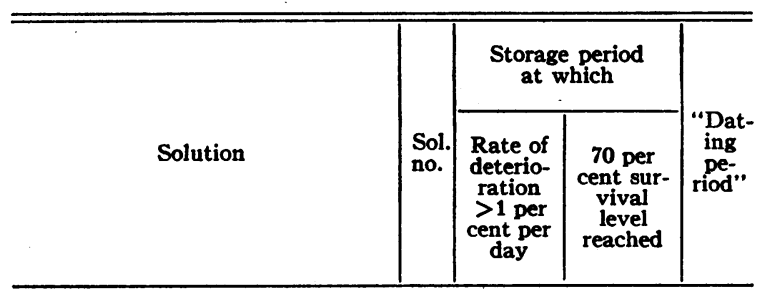

Whole blood

\begin{tabular}{l|r|r|r|r}
\hline Sodium citrate & 1 & 3 & 6 & 5 \\
McGill solution & 2 & 11 & 14 & 12 \\
DeGowin's & 3 & 19 & 24 & 20 \\
Alsever's & 4 & 16 & 20 & 18 \\
Parpart's & 5 & +27 & +27 & 26 \\
ACD-1 & 6 & 27 & 29 & 26 \\
ACD-G & 7 & 22 & +22 & 22 \\
E.T.O. citrate & 8 & 5 & 10 & 7 \\
E.T.O. citrate-saline & 9 & $? *$ & 14 & 10 \\
E.T.O. Mod. A & 10 & 20 & +20 & 20 \\
E.T.O. Mod. B & 11 & $? *$ & +21 & 20 \\
\hline
\end{tabular}

Cells resuspended in electrolyte solutions

\begin{tabular}{|c|c|c|c|c|}
\hline $\begin{array}{l}0.85 \text { per cent saline } \\
10 \text { per cent corn syrup } \\
\text { Phosphate-buffered }\{\mathrm{pH} 6.8 \\
\text { citrate-dextrose } 6 \mathrm{pH} 6.0 \\
\text { Citrate-buffered }\{\mathrm{pH} 5.0 \\
\text { citrate-dextrose } \mathrm{pH} 3.8 \\
\text { Modified }\left\{\mathrm{C}_{2} \mathrm{~A}\right. \\
\text { ACD }\left\{\mathrm{C}_{2} \mathrm{~A}^{1}\right. \\
\text { Modified ACD } \\
\text { (Washington Conference) } \\
\text { Bicarbonate-buffered citrate- } \\
\text { dextrose }\end{array}$ & $\begin{array}{l}12 \\
13 \\
14 \\
15 \\
16 \\
17 \\
18 \\
19 \\
20\end{array}$ & $\begin{array}{r}0 \\
10 \\
+20 \\
? * \\
10 \\
19 \\
11 \\
16 \\
6\end{array}$ & $\begin{array}{r}6 \\
13 \\
+20 \\
23 \\
13 \\
24 \\
19 \\
22 \\
13\end{array}$ & $\begin{array}{r}4 \\
10 \\
20 \\
20 \\
10 \\
20 \\
14 \\
15 \\
9\end{array}$ \\
\hline
\end{tabular}

Cells resuspended in protein-fortified solutions

\begin{tabular}{|c|c|c|c|c|}
\hline $\begin{array}{l}\text { Phosphate-buffered } \\
\text { citrate-dextrose } \\
\text { plus albumin }\end{array}\left\{\begin{array}{l}\mathrm{pH} 6.8 \\
\mathrm{pH} 6.0\end{array}\right.$ & $\begin{array}{l}24 \\
25\end{array}$ & $\begin{array}{r}11 \\
?\end{array}$ & $\begin{array}{l}17 \\
11\end{array}$ & $\begin{array}{r}12 \\
8\end{array}$ \\
\hline $\begin{array}{l}\text { Citrate-buffered } \\
\text { citrate-dextrose } \\
\text { plus globulin }\end{array} \begin{cases}\mathrm{pH} & 7.0 \\
\mathrm{pH} & 3.8\end{cases}$ & $\begin{array}{l}26 \\
27\end{array}$ & $\begin{array}{r}? \\
+23\end{array}$ & $\begin{array}{r}+22 \\
28\end{array}$ & $\begin{array}{l}20 \\
24\end{array}$ \\
\hline
\end{tabular}

Centrifuged cells with and without added saline

\begin{tabular}{l|r|r|r|r}
\hline ACD-1 with saline & 22 & 12 & 18 & 14 \\
ACD-G with saline & 23 & 10 & 19 & 14 \\
without saline & & +21 & +21 & 20 \\
\hline
\end{tabular}

* Observations not made early enough in storage period to determine initial rate of deterioration.

** Second series, Experiments Nos. 140 through 147.

(c) the concentration of dextrose in the diluted plasma after equilibration with the cells is about 0.5 gram per $100 \mathrm{ml}$; ; and

(d) the hydrogen ion concentration is high 
In vivo SURVIVAL OF 'STORED RED CELLS: RADIO-IRON

TABLE VII

Upper safe limits of storage periods for whole blood and cell resuspension solutions

\begin{tabular}{|c|c|c|c|c|}
\hline \multicolumn{5}{|c|}{ Days of storage } \\
\hline $0-5$ & $5-10$ & $10-15$ & $15-20$ & $20-25$ \\
\hline \multicolumn{5}{|c|}{ Whole blood } \\
\hline Sodium citrate & $\begin{array}{l}\text { E.T.O. citrate } \\
\text { E.T.O. citrate } \\
\text { saline }\end{array}$ & McGill & $\begin{array}{l}\text { DeGowin's } \\
\text { Alsever's } \\
\text { E.T.O. Mod. A } \\
\text { E.T.O. Mod. B }\end{array}$ & $\begin{array}{l}\text { Parpart's } \\
\text { ACD-1 } \\
\text { ACD-G }\end{array}$ \\
\hline \multicolumn{5}{|c|}{ Resuspended cells-electrolytes } \\
\hline 0.85 per cent $\mathrm{NaCl}$ & $\begin{array}{l}10 \text { per cent corn syrup } \\
\text { Citrate-buffered } \\
\text { citrate-dextrose } \\
\text { pH } 5.0 \\
\text { Modified ACD } \\
\text { (Wash. Conf.) }\end{array}$ & $\begin{array}{l}\text { Modified ACD } \\
\mathrm{C}_{2} \mathrm{~A} \\
\mathrm{C}_{2} \mathrm{~A}^{1}\end{array}$ & $\begin{array}{c}\text { Phosphate-buffered } \\
\text { citrate-dextrose } \\
\text { pH } 6.8 \\
\text { pH } 6.0 \\
\text { Citrate-buffered } \\
\text { citrate-dextrose } \\
\text { pH 3.8 } \\
\text { Bicarbonate-buffered } \\
\text { citrate-dextrose }\end{array}$ & \\
\hline
\end{tabular}

Resuspended cells-protein-fortified solutions

\begin{tabular}{l|l|l|l|l}
\hline & $\begin{array}{l}\text { Phosphate-buffered } \\
\text { citrate-dextrose } \\
\text { plus albumin }\end{array}$ & $\begin{array}{c}\text { Citrate-buffered } \\
\text { citrate-dextrose } \\
\text { plus globulin }\end{array}$ \\
\hline & & $\begin{array}{l}\text { ACD-1 in saline* } \\
\text { ACD-G in saline }\end{array}$ & ACD-G without saline & \\
\hline
\end{tabular}

* Added just prior to transfusion.

enough so that the buffering action of plasma proteins and hemoglobin will not raise the $\mathrm{pH}$ of the diluted plasma above 7.0 , or of the cells above 6.8 .

These conclusions are in keeping with those of Mollison (35), Loutit (36), and Altmann and Watson (50).

The specifications of the optimal resuspension fluid are, however, less clear.

Since the cells were drawn as whole blood into 4 per cent sodium citrate, some initial damage may have occurred before resuspension.

The addition of dextrose and the maintenance of a slight acidity of the diluent during storage appear to be as important for resuspended cells as for whole blood. No significant hemolysis was produced by the addition of even the most acid fluids.

These observations do not apply to fluids used for resuspension of cells drawn as whole blood into ACD-1 or ACD-G.
Slightly hypertonic solutions of $\mathrm{NaCl}$ with or without low concentrations of dextrose can be safely used for diluting packed ACD red cells provided the diluent is added just prior to transfusions. No electrolyte diluent was found in which packed cells could be stored without increasing their rate of deterioration.

The formation of fibrin clots occurred in more or less degree in all stored blood and resuspended cells. They varied in character from very fine, pale particles to larger, tenacious, gelatinous masses. They were roughly quantitated by inspection of filters and bottles at the end of transfusion. The relative amounts of clot noted are listed in Tables I to IV. Those clots quantitated as $1+$ or $2+$ did not interfere with administration of blood through a cylindrical, metal, 100-mesh screen filter with a $20 \mathrm{sq}$. $\mathrm{cm}$. surface area. Those indicated as $3+$ were in sufficient quantity to slow down the speed of transfusion but not stop flow. The small particles cause obstruction by coating 
the filter surface and are of more significance than the large, stringy masses which might possibly block the outlet from the bottle, although this has not occurred in our experience.

The amount of clot in any given solution tended, in general, to increase on storage at optimal temperature, the oldest bloods showing the largest amounts. The degree of clot formation on storage showed no relationship to ratio of volume of whole blood to anticoagulant used. There was generally less clot present in stored cell resuspensions than in stored whole blood. Albumin solution and saline resuspensions were notable exceptions, both showing relatively large amounts of clot of the stringy, gelatinous type. In stored packed ACD-1 and ACD-G cells, there was much less clot formation than in the same solutions stored as whole blood. None of the solutions studied entirely prevented the formation of clots.

The reactions tabulated in Tables II to $\mathrm{V}$ refer only to those of the febrile type and were probably due to accidental pyrogenic contamination of some part of the collecting, resuspending or transfusion apparatus, or of the solution used, rather than to the breakdown of cells. In many instances there was donor cell destruction equivalent to or greater than that occurring in subjects having a rise in temperature, with no symptoms or fever. In no instance of febrile reaction was bacterial contamination demonstrated. In every case where there was a rise in temperature, there were also malaise and other related symptoms.

In 52 transfusions of whole blood, there were 3 very mild reactions with a maximum temperature rise of $1.5^{\circ} \mathrm{F}$., with no chill, and 1 with a maximum rise of $3.1^{\circ} \mathrm{F}$., with a slight chill. In 81 transfusions of resuspended or packed cells, there were 7 very mild reactions, with a temperature rise of less than $1.0^{\circ} \mathrm{F}$., 5 with a 1.0 to $1.5^{\circ} \mathrm{F}$. temperature rise; and 2 with a temperature rise of 3.1 and $4.4^{\circ} \mathrm{F}$., respectively, and these 2 subjects experienced chills.

There were about twice as many reactions in bloods stored 15 days or less than in those stored more than 15 days. Hence prolonged storage did not increase the incidence of pyrogen reactions.

It is felt that the information obtained from this admittedly small series of well controlled experimental transfusions offers a better basis for evaluating preservatives than observations obtained by less accurate clinical laboratory tests in larger series of observations.

The practical worth of any preservative must finally rest on long-range clinical experience. The conclusions reached herein are set forth as a guide to clinical usage: for the selection of solutions to meet specific requirements and for the establishment of safe storage limits.

\section{CONCLUSIONS}

(1) The post-transfusion survival of preserved human erythrocytes, stored under refrigeration for varying periods of time, has been determined by means of the radioactive iron technic.

(2) Studies were made of 11 preservative solutions for whole blood, of 10 electrolyte solutions for resuspensions of centrifuged cells, of 2 electrolyte resuspension fluids to which human serum protein fractions were added, and of packed cells stored without resuspension after the removal of plasma.

(3) The longest period of time at which cells stored under refrigeration can be safely transfused has been determined for every solution investigated. This "dating period" is based upon the observed rate of deterioration of the red cells during storage.

(4) Refrigeration, the addition of dextrose to the citrate anticoagulant, the maintenance of a slightly acid reaction of the diluted plasma or resuspension fluid, and optimal dilution are essentials for prolonged preservation.

(5) Whole blood can be preserved up to 70 per cent viability for at least 21 days in acid-citrate (ACD-1 and ACD-G), and for at least 15 days in De Gowin's, Alsever's, and McGill solutions.

(6) Red cells drawn as whole blood into sodium citrate can be preserved by resuspension in citratebuffered citrate-dextrose solution for from 10 to 15 days.

(7) Packed red cells from blood drawn into acid-citrate-dextrose may be safely transfused both without the addition of diluent, and with a slightly hypertonic saline diluent added just prior to transfusion, up to 21 days of storage.

\section{ACKNOWLEDGMENTS}

The authors wish to express their appreciation for the devoted assistance of Miss Florence Tytell, Mrs. Virginia Bryant, Miss Eleanor Ryan, Miss Barbara Clapp, and Mrs. Rose Clopman. 
The authors wish to extend their thanks to Dr. Ralph G. Stillman of the New York Hospital, to Maj. Henry Tisdall, M.C., A.U.S., Lt. Henry S. Blakè, U.S.N.R., and Dr. William Thalhimer, for their cooperation in the series of experiments conducted at the New York Hospital.

\section{BIBLIOGRAPHY}

1. Shattock, S. G., Chromocyte clumping in acute pneumonia and certain other diseases, and the significance of the buffy coat in the shed blood. J. Path. \& Bact., 1900, 6, 303.

2. Landsteiner, K., Über Agglutinationserscheinungen normalen menschlichen Blutes. Wein. Klin. Wchnschr., 1901, 14, 1132.

3. Jansky, J., Haematologické, studie u psychotiků. Sborn. klin., 1906-07, 8, 85.

4. Moss, W. L., Studies on isoagglutinins and isohemolysins. Johns Hopkins Hosp. Bull., 1910, 21, 63.

5. Kimpton, A. R., and Brown, J. H., A new and simple method of transfusion. J. A. M. A., 1913, 61, 117.

6. Lindeman, E., Simple syringe transfusion with special cannulas; a new method applicable to infants and adults; preliminary report. Am. J. Dis. Child., 1913, 6, 28.

7. Unger, L. J., A new method of syringe transfusion. J.A.M.A., 1915, 64, 582.

8. Agote, L. Nuevo procedimento para la transfusion de la sangre. Rev. med.-quir., 1920, 1, 3.

9. Lewisohn, R., A new and greatly simplified method of blood transfusion. A preliminary report. Med. Rec., 1915, 87, 141.

10. Hoffman, M. H., and Habein, H. C., Transfusion of citrated blood. J. A. M. A., 1921, 76, 358.

11. Brines, O. A., The transfusing of unmodified blood. Arch. Surg., 1923, 7, 306.

12. Herr, E. A., Blood transfusion to date. Surg., Gynec., \& Obst., 1925, 41, 513.

13. Rous, P., and Turner, J. R., The preservation of living red blood cells in vitro. J. Exper. Med., 1916, 23, 219.

14. Robertson, O. H., Transfusion with preserved red blood cells. Brit. M. J., 1918, 1, 691.

15. Levine, P., and Katzin, E. M., A survey of blood transfusion in America. J. A. M. A., 1938, 110, 1243.

16. Wechselmann, Neuere erfahrungen über intravenöse salvarsaninjektionen ohne reaktionserscheinungen. München Med. Wchnschr., 1911, 58, 1510.

17. Seibert, F. B., Fever-producing substance found in some distilled waters. Am. J. Physiol., 1923, 67, 90.

18. Banks, H. M., Study of hyperpyrexia reaction following intravenous therapy. Am. J. Clin. Path., 1934, 4, 260.

19. Co Tui, McCloskey, K. L., Schrift, M., and Yates, A. L., New method of preparing infusion fluids, based on removal of pyrogen by adsorptive filtration. J. A. M. A., 1937, 109, 250.
20. Lees, J. C., and Levvy, G. A., Emergency preparation of pyrogen-free water. Brit. M. J., 1940, 1, 430.

21. Walter, C. W., Preparation of safe intravenous solutions. Surg., Gynec., \& Obst., 1936, 63, 643.

22. Walter, C. W., Economical intravenous therapy. J. A. M. A., 1935, 104, 1688.

23. Davidsohn, I., Isoagglutinin titers in serum disease, in leukemias, in infectious mononucleosis, and after blood transfusions. Am. J. Clin. Path., 1938, 8, 179.

24. Landsteiner, K., and Wiener, A. S., An agglutinable factor in human blood recognized by immune sera for rhesus blood. Proc. Soc. Exper. Biol. \& Med., 1940, 43, 223.

25. Fantus, B., Therapy of Cook County Hospital; blood preservation. J. A. M. A., 1937, 109, 128.

26. Lundy, J. S., and Osterberg, A. E., Intravenous administration of fluids including blood transfusion. Surg., 1937, 2, 590.

27. Gwynn, C. A., and Alsever, J. B., The collection and preservation of placental blood for transfusion purposes. Am. J. M. Sc., 1939, 198, 634.

28. De Gowin, E. L., Harris, J. E., and Plass, E. D., Studies on preserved human blood. I. Various factors influencing hemolysis. J. A. M. A., 1940, 114, 850.

29. Idem, II. Diffusion of potassium from the erythrocytes during storage. J. A. M. A., 1940, 114, 855.

30. De Gowin, E. L., Harris, J. E., Bell, J., and Hardin, R. C., Osmotic changes in erythrocytes of human blood during storage. Proc. Soc. Exper. Biol. \& Med., 1942, 49, 484.

31. De Gowin, E. L., Hardin, R. C., and Swanson, L. W., Studies on preserved human blood. IV. Transfusion of cold blood into man. J. A. M. A., 1940, 114, 859.

32. De Gowin, E. L., and Hardin, R. C., Studies on preserved human blood. V.I. Reactions from transfusion. J. A. M. A., 1940, 115, 895.

33. Shemin, D., and Rittenberg, D., Studies on the formation of heme and on the average life time of the human red cell. Federation Proceedings, 1946,, Vol. 5, Part II, p. 153.

34. Wiener, A. S., and Schaefer, G., Limitations in the use of preserved blood for transfusion. A study of the fate of the transfused erythrocytes in the recipient's circulation. Med. Clin. N. Amer., 1940, 24, 705 .

35. Mollison, P. L., and Young, I. M., Survival of the transfused erythrocytes of stored blood. Lancet, 1940, 2, 420.

36. Loutit, J. F., Mollison, P. L., and Young, I. M., Citric acid-sodium citrate-glucose mixtures for blood storage; report to Medical Research Council from Southwest London Blood Supply Depot. Quart. J. Exper. Physiol., 1943, 32, 183.

37. De Gowin, E. L., The storage, transportation and administration of whole blood. Blood Substitutes and Blood Transfusion. Charles C. Thomas, Springfield, Ill., 1942, pp. 277-296. 
38. Peacock, W. C., Evans, R. D., Irvine, J. W., Jr., Good, W. M., Kip, A. F., Weiss, S., and Gibson, J. G., 2nd, The use of two radioactive isotopes of iron in tracer studies of erythrocytes. J. Clin. Invest., 1946, 25, 605.

39. Gibson, J. G., 2nd, Weiss, S., Evans, R. D., Peacock, W. C., Irvine, J. W., Jr., Good, W. M., and Kip, A. F., The measurement of the circulating red cell volume by means of two radioactive isotopes of iron. J. Clin. Invest., 1946, 25, 616.

40. Gibson, J. G., 2nd, Aub, J. C., Evans, R. D., Peacock, W. C., Irvine, J. W., Jr., and Sack, T., The measurement of post-transfusion survival of preserved stored human erythrocytes by means of two isotopes of radioactive iron. J. Clin. Invest., 1947, 26, 704.

41. Gibson, J. G., 2nd, and Evelyn, K. A., Clinical studies of the blood volume. IV. Adaptation of the method to the photoelectric microcolorimeter. J. Clin. Invest., 1938, 17, 153.

42. Denstedt, O. F., Osborne, D. E., Stansfield, H., and
Rocklin, I., The survival of preserved red cells after transfusion. Anesthesiology, 1944, 5, 237.

43. De Gowin, E. L., Harris, J. E., and Plass, E. D., Changes in human blood preserved for transfusion. Proc. Soc. Exper. Biol. \& Med., 1939, 40, 126.

44. Parpart, A. K., Personal communication.

45. Rapoport, S., Personal communication.

46. Thalhimer, W., and Taylor, E. S., The transfusion of centrifuged type $\mathrm{O}$ cells, resuspended and stored in 10 per cent corn syrup. J. A. M. A., 1945, 127, 1096.

47. Denstedt, O. F., Personal communication.

48. Strumia, M. M., Personal communication.

49. Gibson, J. G., 2nd, Peacock, W. C., Evans, R. D., Sack, T., and Aub, J. C., The rate of post-transfusion loss of non-viable stored human erythrocytes and the re-utilization of hemoglobin-derived radioactive iron. J. Clin. Invest., 1947, 26, 739.

50. Altmann, A., and Watson, E. F., Survival of transfused erythrocytes of stored blood. South African M. J., 1945, 19, 167. 